NBER WORKING PAPER SERIES

\title{
THE CENTER AND THE PERIPHERY: \\ THE GLOBALIZATION OF FINANCIAL TURMOIL
}

\author{
Graciela L. Kaminsky \\ Carmen Reinhart \\ Working Paper 9479 \\ http://www.nber.org/papers/w9479 \\ NATIONAL BUREAU OF ECONOMIC RESEARCH \\ 1050 Massachusetts Avenue \\ Cambridge, MA 02138 \\ January 2003
}

We have received insightful comments and suggestions from Fernando Broner, Guillermo Calvo, and Takatoshi Ito, as well as participants at presentations held at the Third Joint Central Bank Research Conference on Risk Measurement and Systemic Risk, 2002, Basel, Switzerland; the LACEA 2002 Meeting (Madrid, Spain); Bank of England, Cornell University, George Washington University, London School of Economics, University of Maryland, and University of West Virginia. We are grateful to Amine Mati for superb research assistance. The views expressed herein are those of the authors and not necessarily those of the National Bureau of Economic Research.

(C)2003 by Graciela L. Kaminsky and Carmen Reinhart. All rights reserved. Short sections of text not to exceed two paragraphs, may be quoted without explicit permission provided that full credit including notice, is given to the source. 
The Center and the Periphery: The Globalization of Financial Turmoil Graciela L. Kaminsky and Carmen Reinhart

NBER Working Paper No. 9479

January 2003

JEL No. F0, F20, F30, G15

\section{$\underline{\text { ABSTRACT }}$}

This paper studies how financial turbulence in emerging market countries can spread across borders. We construct indices of "financial globalization" and evaluate the repercussions of turmoil in three emerging markets, which experienced financial crises in the late 1990s: Brazil, Russia, and Thailand. Our findings indicate that financial turbulence in these countries only spreads globally when they affect asset markets in one or more of the world's financial centers. Otherwise, spillovers are confined to countries in the same region. We also find that fragility in institutions in the financial centers is at the core of global spillovers while economic and monetary policy news contributes to regional spillovers.

Graciela L. Kaminsky Department of Economics

George Washington University

Washington, DC 20052

graciela@gwu.edu

\author{
Carmen Reinhart \\ Research Department \\ International Monetary Fund \\ Washington, DC 20431 \\ and NBER \\ crienhart@imf.org
}


The first springs of great events, like those of great rivers, are often mean and little.

Jonathan Swift, 1667-1745

\section{Introduction}

A succession of crises in emerging market economies over the 1990s ignited a debate in academia and policymaking circles about the transmission of shocks across national borders. While it might seem to pre-judge the conclusion, much of this work can be summarized under the heading of "contagion" and, indeed, this word seems apt to capture the spreading market strain surrounding the Mexican peso crisis of 1994, the Asian credit crunch of 1997, and the Russian devaluation and Long-Term Capital Management's (LTCM) implosion of 1998. These episodes have also resuscitated the interest on codes and standards, monetary arrangements, the role of international institutions, and securities law — summarized as the international financial architecture - to construct a bulwark to prevent contagion.

The academic literature on contagion, or less pejoratively described as spillovers and the international propagation of shocks, has progressed along two roads in recent years. Early studies attempted to document the existence of contagion. More recent papers have primarily sought to discriminate among the possible channels of transmission of disturbances - that is, whether shocks propagate through channels established by trade patterns, geography, commonalities among lenders, or from other sources.

In our view, much of this literature suffers from three serious drawbacks. First, most studies have not discriminated among where the shocks originate. One expects, a priori, that the global or regional consequences of a disturbance may depend importantly on whether the shock - to borrow terms from Sir Arthur Lewis- originates in the periphery or in the center. Were the regional consequences of the Thai crisis so severe owing to Thailand's direct links with other countries in the region or because that shock affected the region's largest economy —Japan? Were the paralysis of the bond markets in many parts of the globe and the persistent equity market volatility due to the Russian default or to concerns that LTCM's reach was wider than understood and that other firms in other financial centers of the world share similar failings? And what about the dog that did not bark: Why did Ecuador's 1999 default not have greater 
international consequences? In contrast, in this paper, we attempt to capture the origins of systemic turbulences and measure the direct and indirect linkages among national markets.

Second, terms like contagion and spillover can be quite slippery to define. Some authors seek to learn about potential linkages by examining patterns of correlations across markets using long time series. Others focus on market behavior during specific episodes dated a priori from other sources. Our approach is to define financial turmoil precisely in terms of financial prices and let the data determine when there were episodes of spillover. Specifically, we analyze the daily behavior of stock markets for thirty-five emerging-to-mature market countries from January 1997 to August 1999. Our approach is to focus on the spillover of extreme returns, which are defined as those returns in the $5^{\text {th }}$ and $95^{\text {th }}$ percentile of the distribution. Since we are interested in the center and the periphery, we examine what happens in stock markets around the world on days of turmoil in financial centers (Germany, Japan, and U.S.) and on days of turmoil in crisis-prone emerging economies (Brazil, Russia, and Thailand).

Third, most of the studies in financial spillovers rely on an examination of contemporaneous and lagged correlations. But correlations alone cannot tell apart those systemic turbulences due to a common shock (say a large change in oil prices or the announcement of election results in an important country) and true spillover (a change in one national market directly related to extreme price movements in another market). To learn about the determinants of systemic financial turmoil, we turn to newspapers and summarize the key world events associated with significant price changes. In many cases, this allows us to identify the source of the shock - the center or the periphery - and to understand better the temporal dimension of the financial market adjustment.

To be more specific about spillovers, we borrow from the literature on efficiency of financial markets to distinguish between "weak-form globalization" and "strong-form globalization" of turmoil. Weak-form globalization occurs when country $j$ experiences anomalous returns following an extreme event in country $i$, where anomalous behavior is interpreted as a change in the distribution of returns assessed by a nonparametric procedure. This definition does not require the countries suffering the spillovers to have extreme returns (i.e., to be in the $5^{\text {th }}$ and $95^{\text {th }}$ percentile). Strong-form globalization occurs when country $j$ experiences turmoil when country $i$ is also experiencing financial turbulences. That is, it is a statement about simultaneity of extreme returns. Using these definitions, we construct two indices of 
globalization and examine the patterns of spillover among crisis-prone emerging markets and financial centers. While the analysis of more episodes is clearly necessary, one of the preliminary conclusions we draw from this exercise is that it is important to understand the circuitous route that financial shocks often traverse. Problems occur synchronously in many emerging markets on the periphery because a shock in one of them first influenced a financial center. If the shock never reaches the center, it is doubtful it can become systemic, irrespective of the definition of systemic that is used. For example, in the case of the Asian crisis, Japanese bank exposure to Thailand - and their subsequent retrenchment from lending to other Asian countries- played a prominent role in the spread of the crisis. The role played by the center (i.e. Japan) in this episode was much the same that played by U.S. banks in the 1980s. In the case of Russia, its default triggered a pervasive widening of spreads that hobbled the weakened LTCM and led to a generalized withdrawal of risk taking. Thus, financial centers serve a key role in propagating financial turmoil. When financial centers remain safe, problems in an emerging market stop at the region's border.

The rest of the paper is organized as follows. Section II presents a brief discussion of some of the analytical issues that are relevant to our analysis of globalization of financial turmoil. Section III constructs the two indices of globalization of turmoil and examines the pattern of spillover within and across regions. Section IV discusses the origins of high spillovers. Concluding remarks are presented in Section V.

\section{Analytical Issues}

For the purposes of our analysis, we divide the world into center and periphery countries. The former consist of the countries that house the largest financial centers (i.e., New York, London, Berlin, and Tokyo) while the latter comprise everyone else. We distinguish among three patterns in the propagation of shocks. First, there is the transmission of shocks from one periphery country to another periphery country, which can take place if the two countries are directly linked through bilateral trade or finance (Figure 1). Recent examples of this type of transmission mechanism include the adverse impact of the 1997-98 Asian Crisis on Chilean exports and the contractionary impact on Argentina of the Brazilian devaluation in January 1999. This transmission channel may also be operative if there are bilateral finance links. For instance, 
Costa Rican banks were borrowing from Mexican banks on the eve of the Mexican crisis (see Sara Calvo and Carmen Reinhart, 1996), but when Mexican banks ran into trouble this source of funds disappeared.

Second, there is the transmission of shocks from one periphery country to another via a center country (as shown in Figure 2). There are several prominent examples of this type of transmission mechanism in the literature. Giancarlo Corsetti, Paolo Pesenti, Nouriel Roubini, and Cedric Tille (1998) model trade competition among the periphery countries in a common third "center" market. For instance, Thailand and Malaysia export many of same goods to Japan, Hong Kong, and Singapore. Hence, when Thailand devalued in mid-1997, the crisis spread to Malaysia who lost some of its competitive edge in the common third markets. Guillermo Calvo (1998) suggests that Wall Street may have been the carrier of the "Russian virus" in the fall of 1998; he focuses on asymmetric information and liquidity problems in the financial centers. So, when Russia (a periphery country) defaulted on its bonds, the leveraged investors that held those bonds in the center country faced margin calls and needed to raise liquidity. The margin calls caused them to sell their asset holdings (the bonds and stock of other countries in their portfolio) to an uninformed counterpart. Because of information asymmetries, a "lemons problem" arises and the assets are sold at a firesale price.

A variant of this "financial center" story concerns open-end fund portfolio managers who need to raise liquidity in anticipation of future redemptions. As before, the strategy would be to sell other assets held in the portfolio. The sell-off depresses the asset prices of other countries and the original disturbance spreads across markets. Jeffrey Frankel and Sergio Schmukler (1998) find evidence suggesting that the crisis in Mexico in late 1994 spread to other equity markets in Latin America through New York rather than directly. Graciela Kaminsky, Richard Lyons, and Sergio Schmukler (2001), who examine the behavior of the mutual fund industry in international equity markets, support this venue of spillover. The authors find that in the aftermath of the Thai crisis, the largest mutual fund withdrawals affected Hong Kong and Singapore, which have the most liquid financial markets. Graciela Kaminsky and Carmen Reinhart (2000 and 2001) focus instead on the role of commercial banks lenders in the center country. They stress that following the initial losses due to a crisis in a periphery country, banks' need to rebalance the overall risk of their asset portfolio can lead to a marked reversal in commercial bank lending across the markets where the bank has exposure. By calling loans and 
drying up credit lines to the crisis country, center banks deepen the original crisis. By re-calling loans elsewhere, they propagate the crisis to other countries. The Debt crisis in the early 1980s and the Asian crisis in 1997 provide two clear examples of this mechanism. Following Mexico's default in 1982, United States banks with an extensive exposure to Mexico, spread the crisis across Latin America. In 1997, Japanese banks, heavily exposed to Thailand, played the same role in spreading the crisis throughout Asia.

Third, there is the transmission of symmetric shocks from the center country to the periphery (Figure 3). This is the type of shock stressed in several papers by Guillermo Calvo, Leonardo Leiderman, and Carmen Reinhart (1993, 1996), who analyze how changes in U.S. interest rates influenced capital flows to Latin America in the early part of the 1990s. While an obvious example of this type of shock is changes in interest rates in a financial center country, more subtle ones may include the kinds of regulatory changes in the financial centers discussed in Mohamed El-Erian (1992). Also, the closure of Salomon Brothers' bond arbitrage desk on July 6, 1998 is thought to have been a factor contributing to the loss of liquidity in the market for emerging market bonds, which in turn made markets less resilient.

\section{Financial Globalization: Measures and Determinants}

The crises of the 1990s triggered an immense interest in understanding extreme events. The literature in the late 1990s focused mostly on extreme events in the exchange market as captured by exchange rate devaluations, foreign exchange reserve losses, and in some cases, spikes in overnight interest rates. ${ }^{1}$ Most of this literature focused on either monthly data or even annual data. The goal was to examine whether deteriorating fundamentals were at the root of these crises.

\footnotetext{
${ }^{1}$ See, for example, Graciela Kaminsky and Carmen Reinhart (1999).
} 
But when a variety of countries started to topple like dominoes, many authors began to focus also on the characteristics of contagion. ${ }^{2}$ This literature also deals with issues of systemic risk. But systemic risk is not just connected to currency crises. Systemic risk may also be triggered by shocks in banking and stock or bond markets. Our goal in this section is to present a measure of systemic events triggered by turmoil in a financial market in one country. ${ }^{3}$

We understand financial turmoil as an extreme event in a financial market, be it a rally or a crash. That is, we confine our definition of extreme events to the tail of the distributions of returns by looking at returns in the $5^{\text {th }}$ and $95^{\text {th }}$ percentile of the distribution. Because our interest is in systemic events, we have to consider a substantially large number of markets. Sometimes these systemic events are not long lasting (for example, the worldwide stock market crash in October 1987), implying a need to use high-frequency data. This puts some restrictions on the markets we can examine. To accommodate these needs, we focus on daily returns in stock markets.

Our dataset spans the period beginning on January 1, 1997 through August 31, 1999. We focus on the daily return on equities in the local currency and based on the available local bourse indices. The countries in our sample cover mature- and emerging-market economies, thereby excluding countries with less developed capital markets and a significant extent of financial repression. We can classify the sample into five, somewhat arbitrary, seven-country groupings: The G7 countries, which are comprised of Canada, France, Germany, Italy, Japan, United Kingdom, and the United States; and the transition economies, which include Czech Republic, Estonia, Hungary, Poland, Russia, Slovakia, and Ukraine. The remaining three groups are primarily by region. There is the Asian cluster, which includes Hong Kong, Indonesia, Malaysia, the Philippines, Singapore, South Korea, and Thailand. The other European group, which excludes those countries that are part of the G7, and includes, Finland, Greece, Holland, Norway, Spain, Sweden, and Turkey. Finally, the Latin American sample consists of the larger economies in the region, Argentina, Brazil, Chile, Colombia, Mexico, Peru, and Venezuela.

Table 1 provides summary information on the stock markets examined. Not surprisingly, the degree of instability of stock returns varies considerable across countries. Thus, our

\footnotetext{
${ }^{2}$ See, for example, Barry Eichengreen, Andrew Rose, and Charles Wyplosz (1996), Reuven Glick and Andrew Rose (1998), and Kaminsky and Reinhart (2000).

${ }^{3}$ See also J. Danielsson and C. de Vries (1997), Olivier De Bandt and Philipp Hartmann (2000), F. Longin (1996) and Amine Mati (2001) for studies of extreme returns in stock and bond markets.
} 
definition of extreme events is country-dependent. For example, a drop of 1.8 percent is classified as an extreme event in the United States but it takes a 3.94-percent downfall to qualify as an extreme event in Indonesia. To complete the picture about the stock markets around the world, Table 2 reports sample bilateral correlations. Since the various countries are in different times zones, we provide two measures of bilateral correlations for some countries. For example, Table 2 reports the same day bilateral correlations for countries in Asia and Latin America and also correlations between observations in day $t$ in Latin America and day $t+1$ in Asia. Overall, daily correlations are large for mature markets and somewhat large within regions, but quite small across regions, which does not preclude stock markets around the world from collapsing together on several occasions. For example, on October 28, 1997, 80 percent of the countries in our sample, exhibited extreme returns following the stock market collapse in Hong Kong.

Figure 4 provides the first glimpse of the bunching of turmoil that we are trying to explain. This figure reports the percentage of countries with simultaneous extreme changes in stock prices (those movements in the $5^{\text {th }}$ and $95^{\text {th }}$ percentiles) around the globe or in various regions. The top panel reports the proportion of countries worldwide simultaneously in the $5^{\text {th }}$ or $95^{\text {th }}$ percentile of the distribution. The five other panels show the same evidence by region. The globalization of turmoil is quite evident during the last few days of October 1997 following the collapse of the Hong Kong stock market. However, the phenomenon was short lived, underscoring the importance of daily data. The simultaneous turbulences in the fall of 1998 were quite more persistent. The events that triggered these systemic crashes originated in Russia, starting on June 1, 1998 with the suspension of trading in future markets and were fueled further by the failed auction of Russian GKO government bills on August 27, 1998. On that day, 74 percent of the stock markets around the world collapsed. Turbulence persisted until October as the crisis in Russia was followed by the dislocation in G-7 financial markets as LTCM spiraled downward. The final episode is very short and it is linked to the Brazilian crisis in January 1999. Regional turmoil is far more frequent, with the last half of 1997 plagued by problems in most countries in Asia. In the first half of 1998, the turbulence spreads to Latin America, with turmoil in Brazil at its core. Fragility in mature markets is mostly concentrated in the fall of 1998. Below, we use two definitions of globalization to examine the determinants of world and regional instability. 


\section{Weak-Form Globalization}

This definition focuses on whether turmoil in one country (returns in the 5 th or 95th percentile of the distribution) triggers anomalous behavior in other countries. Anomalous behavior is defined as a change in the distribution of returns. In particular, we estimate the frequency distribution of returns in country $j$ on days of turmoil in country $i$ and the frequency distribution of returns in country $j$ on days of no turmoil in country $i$. We compare these two distributions using the Kolmogorov-Smirnov test of equality of distributions. We classify a country as being affected by extreme crashes or rallies in another country when we reject the null hypothesis of equality of the distributions at a 5 percent significance level or less. We call this phenomenon weak-form globalization from country $i$ to country $j$ because it does not impose simultaneous occurrence of returns in the tails for globalization to occur.

We first examine the degree of weak-form globalization triggered by turmoil in three financial centers: Germany, Japan, and U.S. Table 3 reports the spillover of extreme events with a country-by-country detail. To get a high-resolution picture of anomalous behavior in the stock market, we report the $5^{\text {th }}$ and $95^{\text {th }}$ percentiles of the distribution of returns for all observation in the sample and for the observations on days of market turmoil in each of the financial centers. For example, the $5^{\text {th }}$ and $95^{\text {th }}$ percentile returns for Argentina for the whole sample are -4.31 and 3.41. When there is turmoil in the United States, the $5^{\text {th }}$ and $95^{\text {th }}$ percentile returns for Argentina become -9.37 and 8.13. As shown in this table, the Kolmogorov-Smirnov test rejects the null hypothesis of similar distribution of stock market returns in Argentina on days of financial turmoil in the United States and the distribution on all other days. Thus, we catalogue Argentina as suffering weak-form globalization from turmoil in the United States. In the event, extreme movements in equity markets in the United States are transmitted instantaneously to most Latin American countries - the only exception being Colombia and Venezuela. Indeed, seven-tenth of the countries in Latin America are, according to our measure, affected by toil events in the United States. In contrast, turmoil in the United States triggers an anomalous behavior in only 29 percent of the stock markets of Asian countries. The pattern of the spreading of problems in Japan is in sharp contrast to that observed for the United States. In this case, Latin American markets do not react at all to turmoil in Japan, but 71 percent of the Asian countries experience anomalous returns when Japan posts an outsized return. 
Table 4 summarizes these results. Overall, shocks in financial centers are transmitted instantaneously to basically all (70 percent) mature markets (G-7 and European countries), whether the shock occurs in Germany, Japan, or the United States. These results are suggestive of the higher degree of integration of those markets. The regional characteristics of the transmission of the shocks to emerging economies are, however, different. U.S. shocks are strongly transmitted across Latin America; the shocks in Germany simultaneously affect stock markets in Eastern Europe, Latin American, and Asia; while Japan turbulences mostly affect other Asian countries. Interestingly, this pattern of transmission matches the pattern of exposure of financial institutions in Germany, Japan, and the United States to emerging economies as examined by Caroline van Rijckenghem and Beatrice Weder (2000). These authors classify bank lending to emerging economies by area of origin of those loans. They find that European banks are the largest creditors in all regions, with North American banks concentrating their lending in Latin America and Japanese banks mostly lending to other Asian countries. In particular, at the onset of the Asian crisis, 32 percent of all the international loans to Asian countries originated in Japan, 44 percent originated in Europe, and just 10 percent originated in North America. Also, during 1997 and 1998, most lending to Eastern European (including Russia) countries originated in Western Europe (80 percent) while lending to Latin America originated in Western European banks (60 percent) and North American Banks (30 percent).

Rijckenghem and Weder (2000) also examine the shifts in portfolios of European, North American, and Japanese banks during the Asian and Russian crises. Japanese banks consistently withdrew from Asia, reducing their lending from $\$ 124$ billion in mid-1997 to $\$ 86$ billion by the end of 1998, North American banks mainly shifted their lending among emerging markets during the Asian crisis (from Asia to Latin America and Europe) while they reduced their positions in all three regions during the Russian crisis. European banks continued to build up their positions in all regions even after the onset of the Asian crisis and only during the first half of 1998 did they reduce their holdings in Asia, while increasing them in Latin American and Eastern Europe. The Russian crisis triggered the end of this expansionist investment strategy of European banks in emerging markets, with all banks reducing their exposure to all the three regions by about $\$ 20$ billion.

Table 5 examines whether turmoil is transmitted from one country in the periphery to another country in the periphery or to financial centers. In particular, it examines the pattern of 
spillovers on days of turmoil of three crisis-prone countries in our sample: Brazil, Russia, and Thailand on a country-by-country basis. Table 6 summarizes the information. The patterns of globalization are similar for Brazil and Russia. Turbulence in those countries coincides with abnormal movements around the globe with the sole exception of Asia. Extreme movements in Thailand are not so-far reaching, in that they spill over only to other Asian economies. This evidence begs for an answer as to what are the channels through which these crisis-prone countries with small asset markets have so-far reaching effects. To answer this question, we examine whether the days of turbulence in a particular crisis-prone emerging market were also days of turbulence in a financial center to which that particular country was associated with. We then examine whether problems in crisis-prone emerging markets not associated with turmoil in financial centers also have wide spillover effects. We chose financial centers according to the evidence discussed in the literature. We pair Brazil with the United States, Russia with Germany, and Thailand with Japan.

Table 7 examines the periphery-to-periphery and periphery-center-periphery connections. Days of turmoil in crisis-prone emerging economies are divided in two samples, those on which the corresponding financial center was also roiled and those on which the corresponding financial center was not. The results are dramatically different. Turbulence in Brazil accompanied by turbulence in the United States is transmitted around the world, with Asia being the only region untouched. In contrast, turbulence in Brazil unaccompanied by turbulence in the United States only affects stock markets in Latin America. Turmoil in this case only has a regional reach. The same picture of propagation of shocks is observed in the case of Russian jitters. Turbulence becomes global if a financial center is affected but remains regional when the stock market in the financial center is calm. The evidence from Thailand is somewhat different. Again, simultaneous turmoil in the financial center (Japan) and Thailand triggers a broader propagation of shocks. But here this propagation is only regional in nature. There is not even regional propagation when turbulence affects only the stock market in Thailand. The regional characteristics of some the turbulences in stock markets agree with the evidence from currency crises. $^{4}$

The question is what causes this regional pattern of spillovers. Strong bilateral trade patterns may provide one explanation. For example, Kaminsky and Reinhart (2000) point to the 
strong bilateral trade among Mercosur countries but caution that turmoil in Brazil is still transmitted rapidly to non-Mercosur Latin American countries. Similarly, shocks from Russia are strongly transmitted to most of the transition economies even though bilateral trade links among transition economies diminished drastically in importance following the collapse of the communist regimes in Eastern Europe in 1989-1991. Third party trade links may provide another explanation. For example, Malaysia and Thailand sell similar goods to Japan and the United States, explaining the "contagion" from Thailand to Malaysia following the Thai devaluation in July 1997. But the Mexican crisis in 1994 strongly affected Argentina and Brazil and these countries do not compete with Mexico on third markets. Again financial links may help to explain regional contagion too. For example, Graciela Kaminsky, Richard Lyons, and Sergio Schmukler (2002) examine investment strategies of U.S.-based mutual funds specialized in Latin America and find that they were a key element in explaining the reach of the Tequila crisis: as investors stampeded out of mutual funds specializing in Latin America following the Mexican devaluation, managers (under the pressure of the massive redemptions) had to sell not just Mexican stocks but also stocks from Argentina and Brazil.

Table 8 summarizes these results by region and examines the null hypothesis of financial center irrelevance versus the alternative hypothesis that a financial center has to be affected for the turmoil to become systemic. To examine this hypothesis, we construct the Wilcoxon, or rank-sum, test. To construct this test, we look at the results from the Kolmogorov-Smirnov test and construct two samples as follows. The first sample captures the weak-form globalization pattern following turmoil in a crisis-prone emerging market coinciding with turmoil in a financial center. For each $j$ country in the sample, we assign a value equal to 1 if turmoil in the pair crisis-prone emerging-market and financial center triggers anomalous behavior in country $j$ and zero otherwise. The second sample captures the weak-form globalization pattern following turmoil in a crisis-prone emerging market not coinciding with turmoil in a financial center. Again, for each $j$ country in the sample, we assign a value equal to 1 if turmoil in just the crisisprone emerging market triggers anomalous behavior in country $j$ and zero otherwise. Denote the observations from the first sample by $\{X\}$ and the observations from the second sample by $\{Y\}$. The null hypothesis of financial center irrelevance implies that $P(X>k)=P(Y>k)$ for all $k$. We are interested in the one-sided alternative that $X$ is stochastically larger than $Y$, that is,

\footnotetext{
${ }^{4}$ See, for example, Gelos and Sahay (2000), Glick and Rose (1998), and Kaminsky and Reinhart (2000).
} 
$P(X>k) \$ P(Y>k)$ for all $k$. To construct the rank-sum test, we rank all the observations without regard to the sample to which they belong. Then, the Wilcoxon test statistic is formed as the sum of the ranks in the first sample:

$$
W=\sum_{i=1}^{n} R_{1 i}
$$

where $n$ is the number of countries in each sample. Under the null hypothesis, the average rank of an observation in sample 1 should equal the average rank of an observation in sample 2. Using the Fisher's Principle of Randomization, it is straightforward to verify that:

$$
E(W)=\frac{n(2 n+1)}{2} \quad \text { and } \quad \operatorname{Var}(W)=\frac{n s^{2}}{2}
$$

where $s$ is the standard deviation of the combined ranks $r_{i}$ for both samples:

$$
s^{2}=\frac{1}{2 n-1} \sum_{i=1}^{2 n}\left(r_{i}-\bar{r}\right)^{2}
$$

The last row of Table 8 shows the Wilcoxon test statistic for each sample and the one-sided $p$ value for the null hypothesis of financial-center irrelevance. For example, for the case of Brazil, the proportion of all countries affected when both Brazil and the United States experience turmoil is 76 percent and the proportion of countries affected when just Brazil experiences turmoil is 24 percent. For these two samples, the Wilcoxon $p$-value under the null hypothesis of financial-center irrelevance is less than 0.01 , leading us to reject the null hypothesis of financial center irrelevance. The results for the other two emerging markets are similar. In all cases, the tests reject the null hypothesis of financial-center irrelevance in favor of the alternative hypothesis that a financial center has to be affected for turmoil to become systemic.

\section{Strong-Form Globalization}

In the previous section, we examined whether turmoil in one country triggers anomalous behavior in stock markets around the world, with anomalous behavior defined as a change in the distribution of returns. Under this definition of globalization, other stock markets do not have to experience extreme returns in response to extreme returns in one stock market for globalization to occur. A more stringent concept of globalization of turmoil would be one of simultaneous turmoil. We call this definition of globalization of turmoil "strong-form globalization." A 
globalization index in this case will just be the proportion of countries with simultaneous extreme events. ${ }^{5}$ Our task in this section is to examine the determinants of this index.

To examine the causes of systemic events, we use a multinomial logit approach. We also estimated the model using order logit techniques. The results are quite similar, so we do not report them to save space. Since we are interested in explaining the degree of globalization, our left-hand variable will be a dummy variable that can take three values, low, medium, and high globalization. Low globalization occurs when less than 25 percent of the countries in the sample experience turmoil, medium globalization occurs when there are more than 25 percent but less than 50 percent of the countries in turmoil. Finally, high globalization occurs when 50 percent or more of all the countries experience turmoil. Our explanatory variables are dummy variables capturing days of turmoil in financial centers, days of turmoil in crisis-prone countries on days of turmoil in financial centers, and days of turmoil in crisis-prone countries when financial centers are not affected. These dummies will take a value of one on days of turmoil and zero otherwise. Equation (4) is the multinomial logit equation to be estimated.

$$
\left.P(y=i)=\exp \left(x^{\prime} \beta_{i}\right) /\left(1+\sum_{i=1}^{j-1} x^{\prime} \beta_{i}\right)\right)
$$

The variable $y$ is the globalization index, and the vector $x$ includes the dummy variables capturing turmoil in the various countries. The variable $P(y=i)$ is the probability associated with outcome $i$. The index $j$ refers to the number of outcomes in our estimation: low, medium, and high globalization. The vector $\beta$ is the vector of coefficients to be estimated. As is usual in this type of estimations for each explanatory variable, we estimate $j-1$ parameters. The probability that there is low globalization is our base case and it is equal to:

$$
P(y=\text { low })=1 /\left(1+\sum_{i=1}^{j-1} \exp \left(x^{\prime} \beta_{i}\right)\right)
$$

The estimation of equation (4) is somewhat problematic because not all the markets are open at the same time. Thus, a shock leading to turmoil in Brazil can affect all Latin American economies the same day, it can affect European economies the same day or the following day depending of the time at which the shock occurs, and can only affect Asian countries the

\footnotetext{
${ }^{5}$ In Kaminsky and Reinhart (2000) we constructed a similar index. That time, the index was the proportion of countries with currency crises. That index was used to predict currency crises in other countries. B. Kee-Hong, Andrew Karolyi, and Rene Stulz (2000) also look at simultaneous financial turbulences in Asia and Latin America.
} 
following day. Thus, if a shock occurs in Russia, the index of globalization on the left-hand side has to include countries in turmoil in Europe, the G-7, and Latin America the same day and countries in turmoil in Asia the next day, but if the turmoil originates in Thailand, the index of globalization on the left hand side has to include the number of countries in turmoil in all the regions the same day of the shock.

We deal with this problem in two different ways. First, we estimate equation (4) using only turmoil originating in shocks from one time zone at a time. In this case, the left-hand-side variable is constructed depending on the origin of the shock and we estimate three separate versions of equation (4) for financial centers and three separate versions of equation (4) for crisis-prone emerging markets. The shortcoming of this type of estimation is that we cannot evaluate jointly the effects of extreme events in the various crisis-prone countries and financial centers.

Second, to account for the effect of turbulence in the three crisis-prone countries jointly, we perform panel estimations. To deal with the different time zones, the index of globalization in the left-hand side accounts for low, medium, and high globalization by region. For each region, we align the explanatory variables on the right-hand side according to the region they may affect. Since we estimate the regression for all the regions at the same time, the parameters $\beta$ provide a somewhat different measure of the effects of turmoil in the various countries on globalization. For example, the episodes of high globalization are more confining in the sense that they require all the regions to have a high degree of globalization simultaneously. This was not the case in the non-panel estimation.

Finally, within the panel regression estimates, we jointly evaluate the effects of coincidence of multiple shocks in emerging markets and financial centers. We construct two dummy variables. The first one captures days of turmoil in emerging markets coinciding with turmoil in financial centers. This variable can take four values, zero to three. If this variable takes the value three, it means that the three crisis-prone emerging economies experience turmoil and so do their respective financial centers. The second explanatory variable in this regression will capture the number of crisis-prone emerging markets in turmoil when there is no turmoil in financial centers. Again, this variable can take four values, zero to three.

Tables 9 and 10 examine the effects of turmoil originating in one time zone at a time. Table 9 concentrates on turmoil originating in financial centers. The first equation has as 
explanatory variable a dummy variable equal to one when Germany experiences turmoil and zero otherwise. The second regression has as explanatory variable a dummy variable equal to one when Japan experiences turmoil and zero otherwise. Finally, the third equation has as explanatory dummy variable a dummy variable equal to one when United States experiences turmoil and zero otherwise. Table 10 uses the same methodology to evaluate the degree of globalization following jitters in one turmoil cluster at a time: Brazil-U.S., Russia-Germany, and Thailand-Japan. For each turmoil cluster, the regression has two explanatory dummy variables. One dummy variable is equal to one on days of turbulences in the emerging market coinciding with days of turmoil in the corresponding financial center and zero otherwise. The second explanatory dummy variable is equal to one on days of turbulences in the emerging market not accompanied by turmoil in the corresponding financial center and zero otherwise. To evaluate jointly the contribution of these clusters to the globalization of turmoil, we estimate a multivariate turmoil-cluster panel regression. We estimate the model using panel data because of the time-zone problem. The results are reported in Table 11. Finally, Table 12 reports the panel estimation evaluating the effects of multiple coincidence of turmoil in the three crisis-prone emerging markets. The top panels in all these tables report the estimated coefficients while the bottom panels show the conditional probabilities of globalization obtained from the estimations shown in the top panels.

As for the results, Table 9 shows that turmoil in financial centers triggers turbulences around the world, with the explanatory power (as captured by the pseudo $R^{2}$ ) ranging from 9 percent for turmoil originating in Japan to 19 percent for turmoil originating in Germany. Again, this pattern could be explained, in part, by the higher worldwide exposure of German banks to emerging markets in Asia, Latin America, and Transition economies during the late 1990s. The bottom panel provides another metric to capture the reach of turmoil in the three financial centers: the probability of low, medium, and high globalization conditional on turmoil in each financial center, derived from the multinomial estimation. Again the likelihood of medium to high globalization on days of turmoil in Germany is about 60 percent, but only about 40 percent when shocks originate in Japan, with market jitters in the United States triggering medium-tohigh globalization with a probability of almost 50 percent.

Table 10 reports the results for turmoil originating in emerging markets. The first three columns report the estimates for Brazil, the next three for Russia, and the last three for Thailand. 
As we did when we evaluated weak forms of globalization, we pay particular attention to whether days of turmoil in the three crisis-prone emerging markets coincide with days of turmoil or with days of no turmoil in financial centers. Financial centers would be irrelevant in explaining high degrees of globalization of turmoil if the coefficient $\beta$ attached to the dummy capturing turmoil in the cluster emerging market-financial center is not statistically different from the coefficient $\beta$ attached to the dummy capturing turmoil in just the emerging market. This hypothesis is tested in the third column for each emerging market. In all cases, we reject this hypothesis at all conventional significance levels. To better understand the effects of turmoil in the various countries, the bottom panel of Table 10 also reports the conditional probabilities of low, medium, and high globalization obtained from the estimation of equation (4). The results for Brazil indicate that low globalization is the most likely outcome when turbulence in Brazil does not coincide with turbulence in a financial center. In contrast, when the financial center is also experiencing an extreme event, high globalization becomes the most likely event, with the probability reaching 57 percent. Interestingly, if there is no turmoil in Brazil or the United States, the likelihood of a high clustering of countries with turmoil collapses to 2 percent. The results for Russia are quite similar. Again the necessary ingredient for high globalization is the coincidence of turmoil in Russia and Germany. In this case, the average probability of high globalization is about 50 percent but declines to 2 percent when only Russia experiences turbulence. The results for Thailand indicate that the reach of the Asian crisis was limited in scope. Still, jitters in Thailand are transmitted to other Asian countries only on days of jitters in Japan. The explanatory power of these shocks, as captured by the pseudo $R^{2}$ is high for Brazil and Russia but, as expected, quite small for Thailand.

To evaluate jointly the effects of turmoil in the three emerging markets and financial centers, we report the panel estimates in Tables 11 and 12. As shown in Table 11, each of the three emerging-market-financial center clusters contribute to trigger financial turmoil worldwide, as captured by the statistically significant $\beta$ coefficients of the three crisis-cluster dummies for the high globalization event. Still, the contribution of the Thailand-Japan cluster is somewhat smaller. Our panel estimation, though, has a smaller predictive power than the non-panel estimations on account of the restrictions imposing similar effects of turmoil of the various center-periphery clusters across the five regions. Our more stringent definition of high 
globalization episodes is also reflected in lower probabilities of high globalization following turbulences in the three center-periphery clusters.

Finally, the results in Table 12 bring to the spotlight the magnification effect of simultaneous turbulences in several center-periphery clusters. Note that the probability of high globalization now increases to 94 percent when the three crisis clusters experience turbulences but just 13 percent when one crisis cluster is in turmoil. Note that the probability of high globalization on days of no turmoil in any of the crisis clusters is just 1 percent.

\section{The Origins of Globalization}

In the previous section, we evaluated the odds of simultaneous turbulence around the world when crisis-prone emerging markets and financial centers were experiencing turmoil. We did not explain the origin of these turbulences. To do that, we have to bring in information beyond that on daily movements in equity prices. Our source is the written record: We used reports from Bloomberg, the Financial Times and the Wall Street Journal to construct a chronology of news in those days. We limit our search to days on which at least 50 percent of countries in one region have stock market jitters. This chronology is reported in the Appendix Table. The first column dates the days of regional and global turmoil. The next six columns report the proportion of countries worldwide and by region with stock market turmoil. For clarity, we just report the proportion of markets in turmoil when it reaches more than 50 percent of the countries worldwide or in each region. The last column reports the news. To study the onset and propagation of turmoil, it is important to collect all news, local and foreign, triggering jitters. This news can be about the state of the economy, financial institutions, policies, and just plain rumors. The Appendix Table does not report all the news events that move markets on a particular day, it just reports the most common source of market jitters in the region or around the world.

As shown in this chronology, the first day of worldwide turmoil is October 27, 1997, with 60 percent of the countries around the globe experiencing turmoil. The tension started to build up towards the end of August. Until that time, while several Asian countries experienced turbulences, they did not spread to other countries in that region. But on August 28, 1997, financial markets in Indonesia, Malaysia, the Philippines, Singapore, and Hong Kong collapsed 
amid a deepening loss of confidence in the ability of governments to tackle their severe economic problems. Again, on October 22, turmoil reached Hong Kong and spread in Asia, with about 60 percent of the Asian countries experiencing market crashes. The crisis in Hong Kong deepened and on October 23, it triggered a global sell off in Europe, the G-7 countries, and Latin America. By October 27, worldwide globalization reached about 60 percent of the countries in the sample. This time around, the globalization of the turmoil was short-lived and within two days markets rebounded, with massive rallies around the world.

December 11 is the next day of significant inter-regional spillover, with Korea at the center of the debacle in Asia and Europe. Still, repercussions in the G-7 countries were minor. Another day of inter-regional turmoil was January 12, 1998. At the heart of the jitters was the collapse of Peregrine (Hong Kong), one of Asia's largest investment banks and according to journalists' accounts "raising concerns about emerging markets in general."

The next cluster of global instability started towards the end of May 1998, with Russian tension spreading to Latin America, transition economies, Asia, Europe, and the G-7 countries. The degree of globalization rapidly rose, reaching about 50 percent of countries worldwide by June 15. Rumors of devaluation in China and weakness of the Japanese economy and the yen also contributed to the build up of skittishness. The degree of globalization reached 60 percent on August 11. On August 21, shares of German banks heavily exposed to Russia collapsed triggering downfalls in other G-7 countries. On August 27, the failed auction of Russian GKOs reignited fears of financial collapse, bringing major downturns in 75 percent countries worldwide. Financial turmoil griped Latin American markets following Moody's downgrade of Brazilian and Venezuelan foreign debt while putting Argentina's debt and 11 banks on review for a possible downgrade on September 3. While markets in some regions rebounded during the first week of September, financial concerns, brought again to the limelight by the S\&P's downgrade of Spain's second largest bank (with heavy exposure to Argentina) and of Argentina's two largest banks on September 10, together with LTCM's collapse and bailout on September 24, triggered stock market crashes around the world. This episode of worldwide financial instability came to an end with news of credit easing in financial centers related importantly to the inter-meeting reduction in the federal funds interest rate on October 15 in the United States. 
The last episode of financial instability in our sample occurred around the time of the devaluation of the Brazilian real, which was extremely short-lived. Only on January 13, did financial markets around the world collapse.

The chronology in the Appendix Table suggests that although by construction we have the same number of days of positive and negative turmoil, clusters of world instability occur mostly following adverse shocks. This table also seems to indicate that financial vulnerabilities are at the core of worldwide globalization of turbulences. Table 13 highlights these findings. The top panel shows the proportion of days of rallies and days of crashes during episodes of high regional and world globalization (at least 50 percent of countries affected by turmoil). Note that 85 percent of the episodes of high world globalization involve stock market crashes. Episodes of high regional globalization are more balanced. With the exception of the Asian region, in which days of joint rallies outnumber days of simultaneous crashes, about 60 percent of the days of high regional globalization consist of crashes. The middle panel classifies the days of high globalization, both at a regional level and worldwide, according to the type of news that seems to have triggered the spillover. Financial concerns from bankruptcies of large banks or adverse shocks in one or more asset market in a center country seem to be at the core of high worldwide globalization (40 percent of the episodes). Only 20 percent of the days of high spillovers seem to be driven by economic, political, and monetary news at the center. Another important source of instability is concerns about financial fragility in the periphery ( 25 percent of the episodes). In contrast, financial worries in center countries only account for 26 percent of the episodes of high regional globalization. Financial fragility in the periphery seems to be at the heart of regional turbulences (31 percent of the episodes). Finally, international agreements also contribute to regional turbulences.

One final aspect of globalization that we have still not addressed is whether high globalization occurs when the magnitude of the shocks in the stock market is larger. The bottom panel addresses this question. We first divide extreme returns in three categories according to their size: large (within the 1-percent critical-region on both tails), medium (between the 1percent and 3-percent critical-region on both tails) and small (between the 3-percent and 5percent critical-region). Afterwards, we estimate the average size of the returns for all the countries in turmoil for each episode of low, medium, and high world globalization. The bottom panel in Table 13 shows the proportion of episodes of low, medium, and high world 
globalization with small, medium, and large returns. Larger (in absolute values) returns are more common in days of high globalization: all the shocks in episodes of high globalization are clustered in at the most the 3 percent critical region while during episodes of low globalization 46 percent of the shocks are relatively small (between 3 percent and 5 percent critical region).

\section{Concluding Comments}

This paper presents a new approach to measure and understand systemic financial turbulences. We defined two measures of systemic disturbances: weak- and strong-form globalization and created the corresponding indices of "globalization." These indices allowed us to capture the routes through which market jitters in one country reach other countries in the same region or even worldwide. They also allowed us to estimate the likelihood of low to high globalization following a variety of shocks in crisis-prone emerging markets and financial centers. One of the preliminary conclusions we draw from this exercise is that financial centers are at the core of "systemic" problems: The "worldwide globalization" of the turbulences in Asia in the Fall of 1997 only occurred after the stock market crash in the United States on October 27, while the Russian downfall spread around the globe only after it triggered fragilities in German banks and helped to provoke LTCM's bankruptcy. Without distress in a financial center, disturbances spread at most regionally, with the "silk road" of regional financial distress being in part related to trade links but also to financial linkages. For example, as documented in Kaminsky, Lyons, and Schmukler (2002), the 1994 Mexican crisis spread so rapidly to Argentina and Brazil via the mutual funds (specialized in Latin America) massive withdrawals from those two countries. Finally, our evidence indicates that collapses and not rallies are at the heart of high-globalization episodes, suggesting the need for models with asymmetries to explain systemic turmoil.

Our research has focused on explaining the "geographical" extent of financial turmoil, still the "temporal" dimension of high-globalization episodes of turbulences varies as much, with some episodes lasting just a couple of days (Sell-off in stock markets around the world following the Hong Kong collapse in October 1997) while others, such as the turmoil during the Fall of 1998, lingered much longer. Also, our research, as most of the previous literature, has just focused on a particular asset market. But the degree of systemic problems should not only be 
understood as synchronized jitters across a particular asset market in a variety of countries, but also as simultaneous turmoil across markets in a particular country. Future research should inquire into these differences too. 


\section{References}

Bank for International Settlements, (1999), A Review of Financial Market Events in Autumn 1998, (Basle, Switzerland: Bank for International Settlements), October.

Calvo, Guillermo, (1998). "Capital Market Contagion and Recession: An Explanation of the Russian Virus,” mimeo, University of Maryland.

Calvo, Guillermo A., Leonardo Leiderman, and Carmen M. Reinhart, (1993), "Capital Flows and Real Exchange Rate Appreciation in Latin America: The Role of External Factors," IMF Staff Papers, Volume 40, No. 1, March.

Calvo, Guillermo A., Leonardo Leiderman, and Carmen M. Reinhart, (1996). "Capital Flows to Developing Countries in the 1990s: Causes and Effects", Journal of Economic Perspectives, Vol. 10, Spring, 123-139.

Calvo, Sara and Carmen M. Reinhart, (1996). "Capital Flows to Latin America: Is There Evidence of Contagion Effects?" in Guillermo A. Calvo, Morris Goldstein, and Eduard Hochreitter (eds.) Private Capital Flows to Emerging Markets, (Washington DC: Institute for International Economics).

Corsetti, Giancarlo, Paolo Pesenti, Nouriel Roubini, Cedric Tille, (1998). "Structural Links and Contagion Effects in the Asian Crisis: A Welfare Based Approach," mimeo, Yale University.

Danielsson, J. and C. de Vries, (1997), "Value-at-Risk and Extreme Returns," London School of Economics Working Paper.

De Bandt, Olivier and Philipp Hartmann, (2000). "Systemic Risk: A Survey," European Central Bank Working Paper Series, November.

Eichengreen, Barry, Andrew Rose and Charles Wyplosz, (1996). "Contagious Currency Crises," National Bureau of Economic Research Working Paper No. 5681.

Frankel, Jeffrey and Sergio Schmukler, 1998, "Crises, Contagion, and Country Funds: Effects on East Asia and Latin America," in Reuven Glick (ed.), Managing Capital Flows and Exchange Rates: Perspectives from the Pacific Basin, (New York: Cambridge University Press), pages 232-266.

Gelos, Gastón and Ratna Sahay, (2000), "Financial Market Spillovers in Transition Economies," IMF Working Paper WP/00/71

Glick, Reuven and Andrew Rose, (1998). "Contagion and Trade: Why are Currency Crises Regional?" NBER Working Paper No. 6806. 
Kaminsky, Graciela L., and Carmen M. Reinhart, (1999). "The Twin Crises: The Causes of Banking and Balance-of-Payments Problems," American Economic Review.

Kaminsky, Graciela L. and Carmen M. Reinhart, 2000, “On Crises, Contagion, and Confusion," Journal of International Economics.

Kaminsky, Graciela L., and Carmen M. Reinhart, 2001, "Bank Lending and Contagion: Evidence from the Asian Crisis," in T. Ito and A. Krueger, eds. Regional and Global Capital Flows: Macroeconomic Causes and Consequences, (Chicago: University of Chicago Press for the NBER).

Kaminsky, Graciela, Richard Lyons, and Sergio Schmukler, 2002, "Managers, Investors, and Crises: Mutual Fund Strategies in Emerging Markets," World Bank Working Paper.

Kaminsky, Graciela, Richard Lyons, and Sergio Schmukler, 2001, Economic Fragility, Liquidity, and Risk: The Behavior of Mutual Funds During Crises," World Bank Working Paper.

Kee-Hong, B., G. A. Karolyi, and R. Stulz, (2000), “A New Approach to Measuring Financial Contagion," mimeo.

Longin, F. M., (1996), "The Asymptotic Distribution of Extreme Stock Market Returns," Journal of Business, 69, 383-408.

Mati, Amine, (2001), "Extreme Returns: News and Patterns of Contagion,” George Washington University, mimeo.

Van Rijckeghem, Caroline and Beatrice Weder, (2000). "Financial Contagion: Spillovers through Banking Centers", mimeo, IMF Working Paper. 
Figure 1. The Transmission of Shocks from One Periphery Country to Another

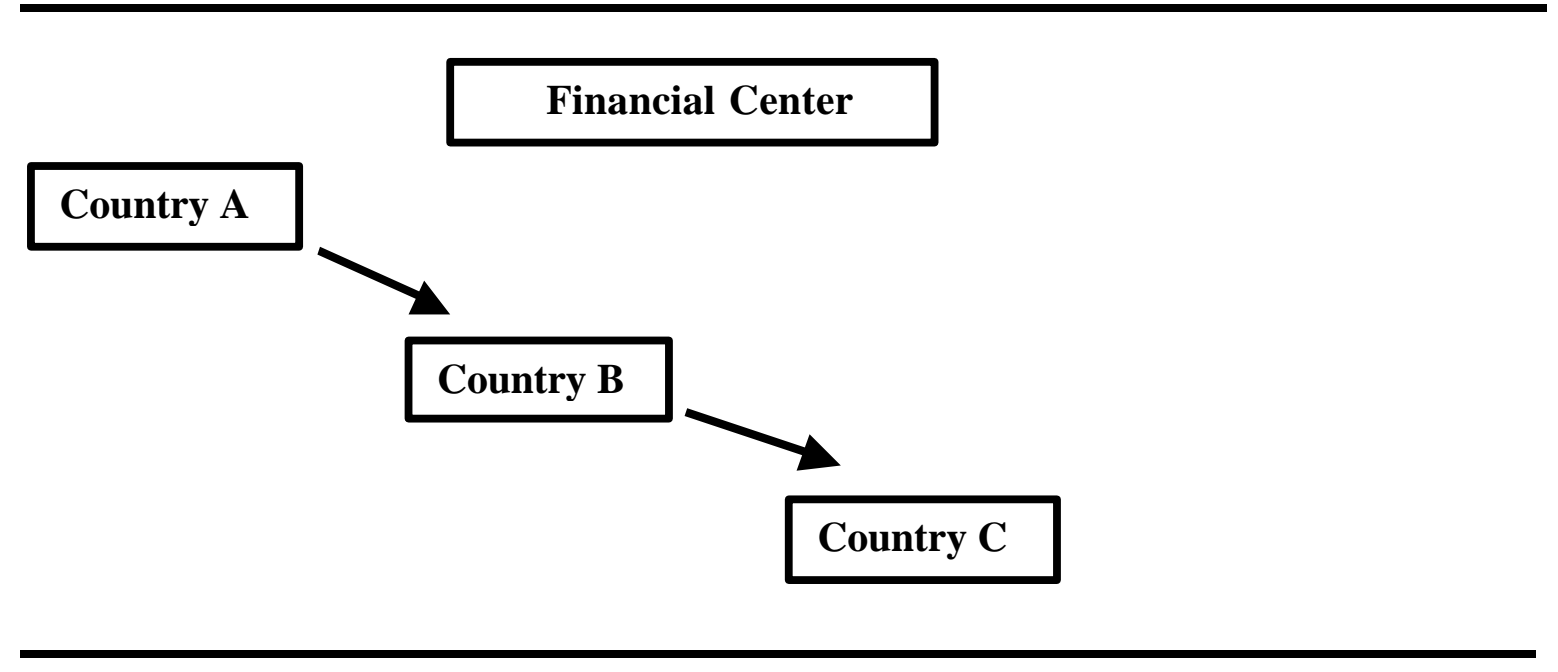

Figure 2. The Transmission of Shocks from one Periphery Country to Another Through a Center Country

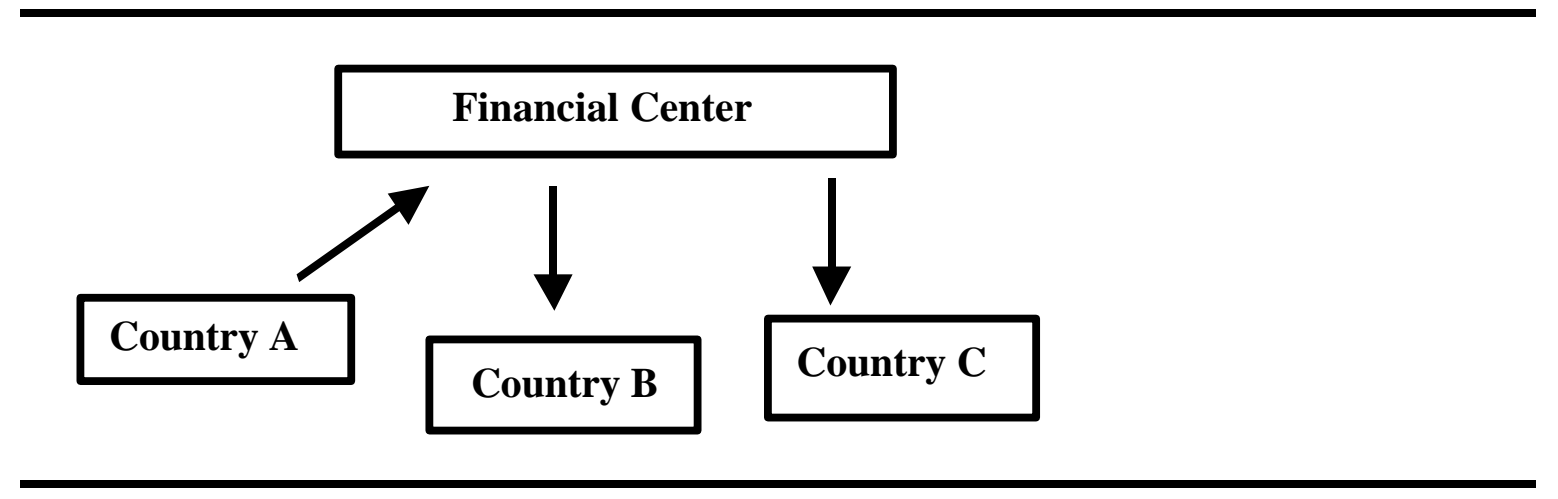

Figure 3. Symmetric Shocks from Center to Periphery

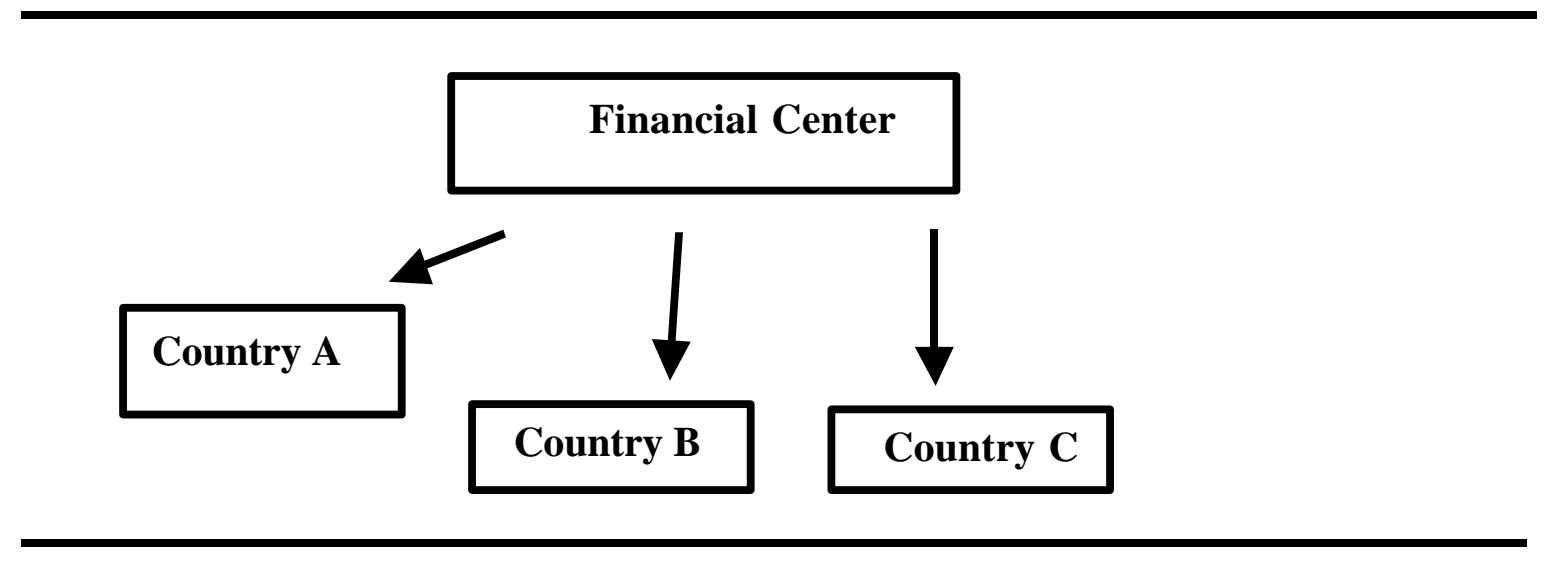


Figure 4

World Globalization
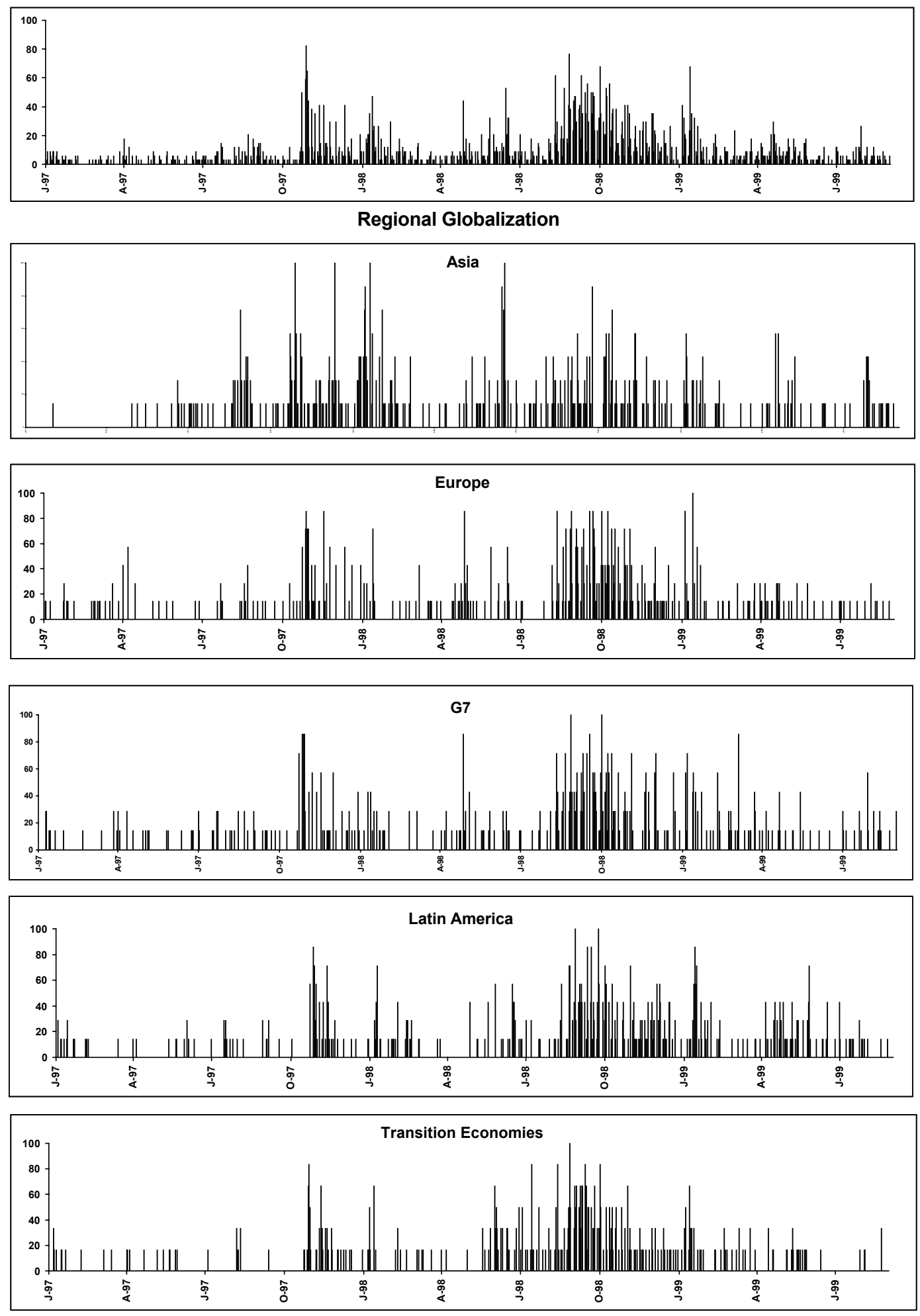

Note: Numbers in the $y$ axis represent the percentage of countries experiencing turmoil. Turmoil is defined as those observations in the 5 th and 95 th percentiles. 
Table 1

Stock Market Returns in Domestic Currency Summary Statistics

\begin{tabular}{|c|c|c|c|}
\hline \multirow{2}{*}{ COUNTries } & \multirow{2}{*}{ mean } & \multicolumn{2}{|c|}{ percentiles } \\
\cline { 3 - 4 } & & 5th & 95th \\
\hline HONG KONG & 1.40 & -3.39 & 3.17 \\
INDONESIA & 1.62 & -3.94 & 4.51 \\
KOREA & 1.96 & -4.43 & 5.32 \\
MALAYSIA & 1.72 & -3.63 & 3.78 \\
PHILIPPINES & 1.41 & -3.26 & 3.46 \\
SINGAPORE & 1.30 & -2.89 & 3.00 \\
THAILAND & 1.78 & -3.49 & 4.74 \\
& & & \\
GREECE & 1.59 & -3.32 & 3.62 \\
FINLAND & 1.31 & -2.79 & 2.82 \\
HOLLAND & 1.16 & -2.42 & 2.46 \\
NORWAY & 1.00 & -2.29 & 2.18 \\
SPAIN & 1.03 & -2.13 & 2.29 \\
SWEDEN & 0.98 & -2.16 & 2.00 \\
TURKEY & 2.49 & -5.75 & 5.82 \\
CANADA & 0.71 & -1.63 & 1.49 \\
FRANCE & 0.90 & -2.02 & 2.01 \\
ITALY & 1.26 & -2.61 & 2.88 \\
GERMANY & 1.20 & -2.54 & 2.27 \\
JAPAN & 0.93 & -1.99 & 2.20 \\
UK & 0.86 & -1.90 & 1.86 \\
USA & 0.87 & -1.80 & 1.90 \\
& & & \\
ARGENTINA & 1.60 & -4.31 & 3.41 \\
BRAZIL & 2.13 & -4.84 & 4.31 \\
CHILE & 1.03 & -2.24 & 2.42 \\
COLOMBIA & 0.83 & -2.01 & 2.17 \\
MEXICO & 1.35 & -2.78 & 3.23 \\
PERU & 1.01 & -2.15 & 2.33 \\
VENEZUELA & 1.55 & -3.98 & 3.48 \\
CZECH REPUBLIC & 0.94 & -2.30 & 2.10 \\
ESTONIA & 1.84 & -4.00 & 4.54 \\
HUNGARY & 1.63 & -3.48 & 3.48 \\
POLAND & 1.35 & -3.02 & 3.03 \\
RUSSIA & 2.49 & -5.10 & 6.48 \\
SLOVAKIA & 0.97 & -2.49 & 2.38 \\
UKRAINE & 2.07 & -5.18 & 5.42 \\
\hline
\end{tabular}

Notes: The sample extends from January 1,1997 to August 31,1999.

Mean is the average of one-day percent returns in absolute values. 
Table 2

Correlation of Stock Market Returns

\begin{tabular}{|c|c|c|c|c|c|c|c|c|c|c|c|c|c|c|c|c|c|c|c|c|c|c|c|c|c|c|c|c|c|c|c|c|c|c|c|}
\hline & HON & IND & KOR & MAL & PHI & SING & THA & GRE & FIN & HOL & NOR & SPA & SWE & TUR & CAN & FRA & GER & ITA & JAP & UK & USA & ARG & BRA & CHI & COL & MEX & PER & VEN & CZE & EST & HUN & POL & RUS & SVK & UKRA \\
\hline HON & 1 & & & & & & & 0.06 & 0.04 & 0.11 & 0.04 & 0.12 & 0.10 & 0.01 & 0.31 & 0.13 & 0.04 & 0.07 & & 0.20 & 0.35 & 0.27 & 0.24 & 0.17 & 0.03 & 0.34 & 0.15 & 0.12 & 0.04 & -0.04 & -0.03 & 0.03 & 0.02 & -0.06 & -0.08 \\
\hline IND & 0.40 & 1.00 & & & & & & 0.05 & 0.12 & 0.19 & 0.08 & 0.18 & 0.15 & 0.09 & 0.31 & 0.20 & 0.14 & 0.13 & & 0.20 & 0.26 & 0.20 & 0.21 & 0.26 & 0.08 & 0.27 & 0.26 & 0.18 & 0.08 & 0.04 & 0.06 & 0.12 & 0.06 & -0.07 & -0.04 \\
\hline KOR & 0.21 & 0.17 & 1.00 & & & & & 0.06 & 0.15 & 0.15 & 0.11 & 0.17 & 0.14 & 0.08 & 0.19 & 0.15 & 0.13 & 0.12 & & 0.20 & 0.21 & 0.19 & 0.16 & 0.13 & 0.02 & 0.19 & 0.16 & 0.13 & 0.07 & 0.02 & 0.10 & 0.09 & 0.15 & 0.08 & -0.06 \\
\hline MAL & 0.35 & 0.29 & 0.21 & 1.00 & & & & -0.03 & 0.08 & 0.07 & 0.06 & 0.11 & 0.08 & 0.00 & 0.24 & 0.11 & 0.09 & 0.01 & & 0.11 & 0.26 & 0.12 & 0.12 & 0.13 & 0.02 & 0.16 & 0.10 & 0.10 & 0.06 & -0.02 & -0.01 & 0.06 & 0.09 & 0.01 & -0.03 \\
\hline PHI & 0.44 & 0.39 & 0.22 & 0.20 & 1.00 & & & 0.12 & 0.23 & 0.27 & 0.21 & 0.27 & 0.22 & 0.11 & 0.33 & 0.26 & 0.24 & 0.25 & & 0.31 & 0.30 & 0.34 & 0.27 & 0.24 & 0.08 & 0.30 & 0.26 & 0.20 & 0.21 & -0.02 & 0.18 & 0.14 & 0.04 & 0.02 & 0.03 \\
\hline SING & 0.68 & 0.50 & 0.24 & 0.40 & 0.53 & 1.00 & & 0.03 & 0.13 & 0.18 & 0.14 & 0.19 & 0.19 & 0.03 & 0.36 & 0.22 & 0.13 & 0.15 & & 0.25 & 0.37 & 0.29 & 0.26 & 0.27 & 0.07 & 0.35 & 0.20 & 0.19 & 0.08 & -0.01 & 0.03 & 0.08 & $\begin{array}{l}-0.02 \\
\end{array}$ & $\begin{array}{l}-0.03 \\
-0.03\end{array}$ & -0.04 \\
\hline THA & 0.36 & 0.40 & 0.28 & 0.32 & 0.35 & 0.47 & 1.00 & 0.07 & 0.11 & 0.15 & 0.10 & 0.20 & 0.13 & 0.05 & 0.24 & 0.17 & 0.14 & 0.15 & & 0.18 & 0.19 & 0.19 & 0.18 & 0.20 & 0.05 & 0.22 & 0.15 & 0.17 & 0.06 & 0.05 & 0.08 & 0.11 & 0.11 & -0.04 & -0.01 \\
\hline GRE & 0.18 & 0.09 & 0.13 & 0.12 & 0.14 & 0.20 & 0.17 & 1.00 & & & & & & & 0.25 & & & & 0.06 & & 0.28 & 0.26 & 0.24 & 0.21 & 0.07 & 0.21 & 0.16 & 0.11 & & & & & & & \\
\hline FIN & 0.41 & 0.19 & 0.16 & 0.20 & & 0.34 & 0.17 & 0.31 & 1.00 & & & & & & 0.3 & & & & 0.16 & & 0.45 & 0.28 & 0.24 & 0.17 & 0.03 & 0.28 & & & & & & & & & \\
\hline $\mathrm{HOL}$ & 0.36 & 0.17 & 0.17 & 0.15 & 0.16 & 0.29 & 0.18 & 0.29 & 0.71 & 1.00 & & & & & 0.23 & & & & 0.20 & & 0.34 & 0.25 & 0.19 & 0.14 & 0.02 & 0.23 & 0.05 & 0.1 & & & & & & & \\
\hline NOR & 0.37 & 0.18 & 0.11 & 0.20 & 0.20 & 0.36 & 0.19 & 0.28 & 0.67 & 0.63 & 1.00 & & & & 0.27 & & & & 0.12 & & 0.36 & 0.26 & 0.22 & 0.19 & 0.00 & 0.25 & 0.12 & 0.11 & & & & & & & \\
\hline SPA & 0.29 & 0.17 & 0.11 & 0.10 & 0.17 & 0.25 & 0.13 & 0.31 & 0.63 & 0.72 & 0.56 & 1.00 & & & 0.24 & & & & 0.21 & & 0.30 & 0.28 & 0.24 & 0.19 & 0.03 & 0.29 & 0.12 & 0.10 & & & & & & & \\
\hline SWE & 0.38 & 0.16 & 0.16 & 0.16 & 0.17 & 0.31 & 0.16 & 0.31 & 0.76 & 0.74 & 0.67 & 0.69 & 1.00 & & 0.27 & & & & 0.19 & & 0.36 & 0.31 & 0.25 & 0.18 & 0.02 & 0.25 & 0.12 & 0.14 & & & & & & & \\
\hline TUR & 0.13 & 0.09 & 0.11 & 0.11 & 0.02 & 0.11 & 0.18 & 0.16 & 0.29 & 0.26 & 0.27 & 0.22 & 0.27 & 1.00 & 0.11 & & & & 0.05 & & 0.16 & 0.15 & 0.15 & 0.14 & 0.03 & 0.18 & 0.09 & 0.07 & & & & & & & \\
\hline CAN & 0.26 & 0.10 & 0.09 & 0.09 & 0.16 & 0.24 & 0.14 & 0.22 & 0.43 & 0.45 & 0.39 & 0.48 & 0.47 & 0.21 & 1.00 & 0.25 & 0.31 & 0.19 & 0.30 & 0.27 & & & & & & & & & 0.20 & 0.16 & 0.32 & 0.49 & 0.17 & 0.05 & -0.01 \\
\hline FRA & 0.35 & 0.16 & 0.15 & 0.16 & 0.17 & 0.30 & 0.16 & 0.29 & 0.72 & 0.78 & 0.62 & 0.77 & 0.77 & 0.26 & 0.48 & 1.00 & & & 0.19 & & 0.35 & 0.27 & 0.24 & 0.14 & 0.03 & 0.25 & 0.06 & 0.09 & & & & & & & \\
\hline GER & 0.43 & 0.20 & 0.15 & 0.17 & 0.21 & 0.33 & 0.18 & 0.28 & 0.72 & & 0.66 & 0.68 & 0.70 & 0.25 & 0.45 & 0.75 & 1.00 & & 0.16 & & 0.44 & 0.33 & 0.28 & 0.18 & 0.01 & 0.29 & 0.11 & 0.16 & & & & & & & \\
\hline ITA & 0.26 & 0.12 & 0.12 & 0.11 & 0.12 & 0.22 & 0.11 & & 0.63 & & 0.5 & 75 & 0.67 & 0.2 & 0.40 & 0.76 & 0.62 & 1.00 & 0.13 & & & 0.24 & 0.18 & 0.13 & 0.05 & 0.22 & 0.04 & 0.05 & & & & & & & \\
\hline JAP & 0.37 & 0.23 & 0.19 & 0.23 & 0.20 & 0.33 & 0.19 & & & 0. & 0.28 & 24 & 0 & 0. & 0.21 & 0.3 & 0.29 & 0.23 & 1.00 & 0.24 & 33 & 0.27 & 0.27 & 0.21 & 0.03 & 0.29 & 0.16 & 0.12 & 0.09 & -0.05 & 0.06 & -0.01 & 0.05 & -0.06 & 0.03 \\
\hline UK & 0.39 & 0.16 & 0.20 & 0.23 & 0.22 & 0.3 & 0.21 & & & 0.74 & 0.60 & & & 0.24 & 0.45 & 0.75 & 0.68 & 0.66 & 0.32 & 1.00 & 0.34 & 0.24 & 0.23 & 0.11 & 0.02 & 0.21 & 0.02 & 0.09 & 0.05 & -0.05 & 0.00 & -0.01 & 0.05 & -0.00 & 0.05 \\
\hline USA & 0.12 & -0.02 & 0.09 & -0.03 & 0.10 & 0.12 & 0.05 & 0.11 & 0.35 & 0.37 & 0.27 & 0.38 & 0.35 & 0.11 & 0.73 & 0.40 & 0.34 & 0.33 & 0.08 & 0.38 & 1.00 & & & & & & & & 0.18 & 0.14 & 0.39 & 0.55 & 0.20 & 0.00 & 0.00 \\
\hline ARG & 0.21 & & & 0.12 & & & 0.17 & & & & 0.2 & & & & & & & & & & & 1.00 & & & & & & & & & & & & & \\
\hline BRA & 0.13 & 0.01 & 0. & 0.03 & 0.12 & & 0.1 & & & & 0. & & & & 0.4 & 0. & 0.26 & 0.27 & 0.12 & 0.32 & 0.54 & 0.71 & 1.00 & & & & & & & & & 0. & 0.19 & & \\
\hline $\mathrm{CHI}$ & 0.21 & 0.11 & 0.12 & 0.04 & 0.20 & 0.21 & 0.16 & 0.12 & 0.31 & 0.32 & 0.30 & 0.37 & 0.30 & 0.13 & 0.38 & 0.35 & 0.31 & 0.30 & 0.15 & 0.35 & 0.41 & 0.52 & 0.52 & 1.00 & & & & & 0. & 0.0 & & & 0.14 & & 0.10 \\
\hline COL & 0.10 & 0.11 & 0.05 & 0.07 & 0.06 & 0.07 & 0.06 & 0.05 & 0.17 & 0.1 & 0.1 & 16 & 0 & 0. & 0.1 & 0.1 & 0. & 0. & 0.06 & 0.15 & 0.09 & 0.11 & 0.07 & 0.15 & 1.00 & & & & 0. & 0. & & & 1 & & \\
\hline MEX & 0.19 & 0.02 & 0.10 & 0.11 & 0.15 & 0.16 & 0.10 & 0.1 & 0.30 & 0.33 & 0.26 & 35 & 0.28 & 0.1 & 0.52 & 0.3 & 0.2 & 0. & 0.13 & 0.35 & 0.57 & 0.64 & 0.65 & 0.51 & 0.06 & 1.00 & & & & 0. & & & 25 & 0.00 & 0.06 \\
\hline PER & 0.23 & 0.15 & 0.09 & 0.14 & 0.19 & 0.19 & 0.17 & 0.18 & 0.35 & 0.34 & 0.37 & 0.38 & 0.36 & 0.23 & 0.38 & 0.36 & 0.32 & 0.35 & 0.16 & 0.36 & 0.30 & 0.47 & 0.45 & 0.41 & 0.18 & 0.45 & 1.00 & & 0.10 & 0.07 & 0.27 & 0.30 & 0.11 & 0.01 & 0.13 \\
\hline VEN & 0.21 & 0.16 & 0.10 & 0.10 & 0.14 & 0.22 & 0.19 & 0.09 & 0.24 & 0.26 & 0.28 & 0.30 & 0.32 & 0.18 & 0.30 & 0.25 & 0.25 & 0.24 & 0.15 & 0.29 & 0.20 & 0.35 & 0.29 & 0.30 & 0.12 & 0.32 & 0.31 & 1.00 & 0.13 & 0.03 & 0.19 & 0.18 & 0.10 & 0.02 & 0.04 \\
\hline CZE & 0.22 & 0.15 & & 0.14 & 0.16 & & 0.17 & & & & & & & & & & 0.34 & & & & & & & & & & & & 1. & & & & & & \\
\hline & 0.18 & 0.09 & 0.03 & 0.09 & 0.09 & 0. & 0.10 & 0.11 & 0.13 & 0.11 & $0 . c$ & 0.08 & 0. & 0.04 & 0.04 & 0.14 & 0.1 & 0. & & 0. & 0.02 & 0.00 & 0.00 & 0.03 & 0.01 & 0.01 & -0.01 & & 0.08 & 1.00 & & & & & \\
\hline HUN & 0.41 & 0.26 & 0.25 & 0.20 & 0.24 & 0.36 & 0.21 & 0.29 & 0.50 & 0.46 & 0.45 & 0.45 & 0.46 & 0.32 & 0.28 & 0.46 & 0.48 & 0.41 & 0.33 & 0.43 & 0.14 & 0.22 & 0.14 & 0.24 & 0.14 & 0.15 & 0.28 & 0.24 & 0.40 & 0.17 & 1.00 & & & & \\
\hline & 0.43 & 0.2 & 0.2 & 0.30 & 0.3 & & 0.2 & 0.3 & 0.4 & 0.3 & 0.4 & 0.3 & 0.43 & 0.2 & 0.2 & 0.3 & 0.4 & 0. & 0. & & & 0.15 & 0. & & & 0.12 & & & & & & 1.00 & & & \\
\hline RUS & 0.2 & 0.1 & 0. & 0.2 & 0.1 & & 0.2 & & 0. & 0. & & 0.2 & 0.2 & 0.2 & 0.1 & 0.2 & 0.2 & 0.2 & 0.19 & & 0.0 & 0.1 & 0. & & & & & & & & & & & & \\
\hline & 0.0 & 0.0 & & & 0.0 & & 0. & & & & -0. & -0.6 & & & 0.0 & -0. & & & & -0. & -0. & 0. & & & -0. & & & & & & & & & & \\
\hline UKRA & 0.05 & 0.02 & 0.04 & -0.01 & 0.03 & 0.11 & 0.01 & 0.07 & 0.08 & 0.01 & 0.11 & 0.05 & 0.14 & 0.02 & 0.16 & 0.06 & 0.08 & 0.08 & 0.06 & 0.06 & 0.11 & 0.15 & 0.13 & 0.18 & 0.16 & 0.08 & 0.09 & 0.07 & 0.12 & 0.00 & 0.07 & 0.12 & 0.06 & -0.01 & 1.00 \\
\hline
\end{tabular}

Notes: The lower triangular part of the correlation matrix reports the correlation on the same day. Since markets are not open at the same time, shocks to some countries will be transmitted to some regions the following day. The upper triangular part of the matrix reports the correlation between the returns of the countries listed in the column in day $t$ with returns of the countries listed on top on day $\mathrm{t}+1$ or day $\mathrm{t}-1$ as appropriate. 
Table 3

Turmoil in Financial Centers: How Does It Spread?

\begin{tabular}{|c|c|c|c|c|c|c|c|c|c|c|c|c|c|c|c|}
\hline \multirow{4}{*}{ COUNTRIES } & \multicolumn{15}{|c|}{ Empirical Distribution of Stock Market Returns } \\
\hline & \multirow{3}{*}{ mean } & \multicolumn{2}{|c|}{ N ALL DAYS } & \multicolumn{4}{|c|}{ ON DAYS OF TURMOIL IN GERMANY } & \multicolumn{4}{|c|}{ ON DAYS OF TURMOIL IN JAPAN } & \multicolumn{4}{|c|}{ ON DAYS OF TURMOIL IN USA } \\
\hline & & \multicolumn{2}{|c|}{ Percentiles } & \multirow{2}{*}{ mean } & \multicolumn{2}{|c|}{ Percentiles } & \multirow{2}{*}{$\begin{array}{c}\text { K\&S } \\
\text { p-value }\end{array}$} & \multirow{2}{*}{ mean } & \multicolumn{2}{|c|}{ Percentiles } & \multirow{2}{*}{$\begin{array}{c}\mathrm{K} \& S \\
\mathrm{p} \text {-value }\end{array}$} & \multirow{2}{*}{ mean } & \multicolumn{2}{|c|}{ Percentiles } & \multirow{2}{*}{$\begin{array}{c}\mathrm{K} \& S \\
p \text {-value }\end{array}$} \\
\hline & & 5th & 95th & & 5th & 95th & & & 5th & 95th & & & 5th & 95th & \\
\hline HONG KONG & 1.40 & -3.39 & 3.17 & 2.08 & -4.92 & 5.07 & 0.44 & 2.60 & -6.61 & 7.41 & *** & 2.40 & -3.92 & 7.01 & ${ }^{* *}$ \\
\hline INDONESIA & 1.62 & -3.94 & 4.51 & 2.55 & -5.24 & 7.41 & ** & 2.74 & -4.76 & 7.30 & $* * * *$ & 2.17 & -4.84 & 7.12 & $* * *$ \\
\hline KOREA & 1.96 & -4.43 & 5.32 & 2.22 & -4.97 & 6.35 & 0.98 & 2.81 & -5.52 & 7.26 & $* * * *$ & 2.41 & -5.45 & 6.87 & 0.76 \\
\hline MALAYSIA & 1.72 & -3.63 & 3.78 & 2.38 & -4.80 & 5.89 & $* *$ & 2.63 & -5.37 & 5.71 & 0.06 & 2.58 & -6.15 & 9.09 & 0.52 \\
\hline PHILIPPINES & 1.41 & -3.26 & 3.46 & 2.23 & -5.54 & 4.21 & **** & 2.00 & -4.95 & 5.83 & *** & 1.84 & -4.86 & 4.31 & 0.51 \\
\hline SINGAPORE & 1.30 & -2.89 & 3.00 & 1.95 & -4.66 & 4.23 & 0.18 & 2.27 & -3.93 & 7.00 & $* * *$ & 1.85 & -3.62 & 3.85 & 0.23 \\
\hline THAILAND & 1.78 & -3.49 & 4.74 & 2.09 & -4.05 & 6.10 & 0.69 & 2.38 & -3.94 & 8.16 & 0.47 & 1.83 & -3.54 & 7.52 & 0.21 \\
\hline GREECE & 1.59 & -3.32 & 3.62 & 2.06 & -6.13 & 3.60 & 0.06 & 2.17 & -6.12 & 5.07 & 0.10 & 2.39 & -5.57 & 4.93 & 0.06 \\
\hline HOLLAND & 1.16 & -2.42 & 2.46 & 2.77 & -5.21 & 4.89 & **** & 1.75 & -3.85 & 3.80 & $* *$ & 1.69 & -4.54 & 3.33 & $* *$ \\
\hline NORWAY & 1.00 & -2.29 & 2.18 & 2.49 & -5.39 & 5.05 & $* * *$ & 1.68 & -4.95 & 5.05 & *** & 1.53 & -4.64 & 4.44 & $* *$ \\
\hline SPAIN & 1.03 & -2.13 & 2.29 & 2.40 & -6.03 & 5.12 & $* * *$ & 1.58 & -4.79 & 4.01 & $* *$ & 1.31 & -3.69 & 3.78 & 0.30 \\
\hline SWEDEN & 0.98 & -2.16 & 2.00 & 2.18 & -4.34 & 3.21 & $* * *$ & 1.74 & -4.07 & 3.28 & $* * * *$ & 1.47 & -3.71 & 3.31 & ${ }^{* * *}$ \\
\hline TURKEY & 2.49 & -5.75 & 5.82 & 3.74 & -10.12 & 9.26 & 0.06 & 3.56 & -10.12 & 8.78 & 0.12 & 3.45 & -8.85 & 9.89 & ** \\
\hline CANADA & 0.71 & -1.63 & 1.49 & 1.36 & -3.72 & 2.75 & $* * *$ & 0.93 & -2.04 & 1.67 & 0.07 & 1.83 & -3.72 & 2.90 & $* * *$ \\
\hline FRANCE & 0.90 & -2.02 & 2.01 & 2.22 & -4.29 & 4.45 & $* * * *$ & 1.42 & -3.94 & 3.47 & $* * *$ & 1.23 & -3.34 & 3.11 & 0.15 \\
\hline ITALY & 1.26 & -2.61 & 2.88 & 2.59 & -5.63 & 5.29 & **** & 2.02 & -5.23 & 4.48 & $* *$ & 1.61 & -4.33 & 4.96 & $* *$ \\
\hline GERMANY & 1.20 & -2.54 & 2.27 & 3.57 & -5.87 & 5.17 & $* * * *$ & 1.88 & -4.67 & 4.21 & $* *$ & 1.90 & -5.35 & 3.94 & $* * *$ \\
\hline JAPAN & 0.93 & -1.99 & 2.20 & 1.20 & -3.07 & 2.84 & *** & 2.95 & -4.15 & 4.37 & $* * *$ & 1.19 & -2.79 & 2.77 & 0.62 \\
\hline UK & 0.86 & -1.90 & 1.86 & 1.79 & -3.25 & 3.32 & $* * *$ & 1.23 & -2.96 & 2.67 & $* *$ & 1.19 & -3.06 & 3.00 & ${ }^{* *}$ \\
\hline USA & 0.87 & -1.80 & 1.90 & 1.39 & -3.42 & 3.10 & 0.18 & 0.97 & $\begin{array}{l}-2.06 \\
\end{array}$ & 2.12 & 0.28 & 2.60 & -3.73 & 4.02 & $* * *$ \\
\hline BRAZIL & 2.13 & -4.84 & 4.31 & 3.73 & -9.77 & 8.07 & $* *$ & 2.73 & -9.71 & 4.72 & 0.32 & 4.76 & -10.08 & 10.34 & $* * *$ \\
\hline CHILE & 1.03 & -2.24 & 2.42 & 1.71 & -5.04 & 3.23 & $* *$ & 1.05 & -2.79 & 2.39 & 0.43 & 1.78 & -4.69 & 3.55 & $* *$ \\
\hline COLOMBIA & 0.83 & -2.01 & 2.17 & 0.89 & -2.38 & 2.30 & 0.79 & 1.04 & -2.28 & 3.93 & 0.11 & 0.88 & -2.42 & 1.95 & 0.88 \\
\hline MEXICO & 1.35 & -2.78 & 3.23 & 2.67 & -6.05 & 5.29 & $* *$ & 1.98 & -4.79 & 4.20 & 0.09 & 2.95 & -6.05 & 7.17 & $* * *$ \\
\hline PERU & 1.01 & -2.15 & 2.33 & 1.85 & -5.75 & 4.58 & $* * *$ & 1.29 & -3.02 & 2.88 & 0.29 & 1.66 & -4.70 & 3.97 & $* *$ \\
\hline VENEZUELA & 1.55 & -3.98 & 3.48 & 2.25 & -7.51 & 4.32 & 0.26 & 1.72 & -5.09 & 2.32 & 0.06 & 2.04 & -6.20 & 3.77 & 0.13 \\
\hline CZECH REPUBLIC & 0.94 & -2.30 & 2.10 & 1.62 & -4.28 & 2.82 & $* * *$ & 1.18 & -2.99 & 2.09 & 0.14 & 1.31 & -3.48 & 2.33 & $* *$ \\
\hline ESTONIA & 1.84 & -4.00 & 4.54 & 2.80 & -8.35 & 8.25 & 0.16 & 2.97 & -11.31 & 9.09 & 0.09 & 2.38 & -8.35 & 5.36 & 0.43 \\
\hline HUNGARY & 1.63 & -3.48 & 3.48 & 3.48 & -10.03 & 4.94 & $* * *$ & 3.47 & -10.76 & 8.63 & $* * *$ & 3.26 & -10.76 & 9.10 & $* * *$ \\
\hline POLAND & 1.35 & -3.02 & 3.03 & 2.34 & -6.02 & 5.28 & $* * * *$ & 2.42 & -6.41 & 4.81 & 0.09 & 2.90 & -6.60 & 6.53 & $* * *$ \\
\hline RUSSIA & 2.49 & -5.10 & 6.48 & 4.73 & -10.80 & 14.98 & $* * *$ & 3.82 & -10.11 & 7.46 & 0.10 & 4.19 & -12.49 & 14.67 & 0.07 \\
\hline SLOVAKIA & 0.97 & -2.49 & 2.38 & 1.09 & -3.13 & 2.35 & 0.71 & 0.96 & -2.56 & 1.82 & 0.30 & 0.83 & -2.58 & 1.94 & 0.37 \\
\hline UKRAINE & 2.07 & -5.18 & 5.42 & 3.15 & -12.20 & 6.06 & 0.08 & 3.10 & -11.07 & 8.09 & 0.13 & 3.02 & -8.63 & 7.04 & 0.26 \\
\hline
\end{tabular}

Notes: Turmoil is defined as those observations in the 5 th and 95 th percentiles. Mean is the average of one day percent returns in absolute values. The Kolmogorov Smirnov Test evaluates whether the frequency distribution on days of turmoil in the corresponding financial center is different from the frequency distribution on all other days. 5th and 95th percentiles report the the values of stock market returns at those percentiles. The sample extends from January 1,1997 to August 31,1999. ${ }^{\star * * * * *}$, represent the significance of the Kolmogorov Smirnov Test at the 1
and 5 percent level respectively. 
Table 4

Weak-Form Globalization of Turmoil

Regional and World Effects

\begin{tabular}{|c|c|c|c|}
\hline \multirow{2}{*}{ REGIONS } & \multicolumn{2}{|c|}{ Percentage of Countries with Anomalous Returns when Turmoil in } \\
\cline { 2 - 4 } & GERMANY & JAPAN & USA \\
\hline Asia & 43 & 71 & 71 \\
Europe & 71 & 71 & 75 \\
G7 & 100 & 0 & 71 \\
Latin America & 43 & 14 & 43 \\
Transition Economies & 57 & 44 & 56 \\
World & 59 & 45 \\
\hline
\end{tabular}

Notes: Turmoil is defined as those observations in the 5th and 95th percentiles.

An anomalous return is interpreted as a change in the distribution of returns in country j on days of turmoil in country $i$. 
Table 5

Turmoil in Emerging Markets: How Does It Spread?

\begin{tabular}{|c|c|c|c|c|c|c|c|c|c|c|c|c|c|c|c|}
\hline \multirow{4}{*}{ COUNTRIES } & \multicolumn{15}{|c|}{ Empirical Distribution of Stock Market Returns } \\
\hline & \multicolumn{3}{|c|}{ ON ALL DAYS } & \multicolumn{4}{|c|}{ ON DAYS OF TURMOIL IN BRAZIL } & \multicolumn{4}{|c|}{ ON DAYS OF TURMOIL IN RUSSIA } & \multicolumn{4}{|c|}{ ON DAYS OF TURMOIL IN THAILAND } \\
\hline & \multirow{2}{*}{ mean } & \multicolumn{2}{|c|}{ Percentiles } & \multirow{2}{*}{ mean } & \multicolumn{2}{|c|}{ Percentiles } & \multirow{2}{*}{$\begin{array}{c}\text { K\&S } \\
\text { p-value }\end{array}$} & \multirow{2}{*}{ mean } & \multicolumn{2}{|c|}{ Percentiles } & \multirow{2}{*}{$\begin{array}{c}\text { K\&S } \\
\text { p-value }\end{array}$} & \multirow{2}{*}{ mean } & \multicolumn{2}{|c|}{ Percentiles } & \multirow{2}{*}{$\begin{array}{c}\text { K\&S } \\
p \text {-value }\end{array}$} \\
\hline & & 5th & 95th & & 5 th & 95th & & & 5th & 95th & & & 5th & 95th & \\
\hline HONG KONG & 1.40 & -3.39 & 3.17 & 2.41 & -4.82 & 7.41 & 0.32 & 2.05 & -3.26 & 6.84 & 0.17 & 2.45 & -4.52 & 6.84 & ***; \\
\hline INDONESIA & 1.62 & -3.94 & 4.51 & 2.50 & -5.15 & 6.77 & $* *$ & 2.32 & -5.15 & 6.47 & 0.30 & 2.89 & -5.03 & 8.00 & $* *$ \\
\hline KOREA & 1.96 & -4.43 & 5.32 & 2.60 & -5.65 & 6.76 & 0.37 & 2.18 & -4.97 & 4.91 & 0.49 & 2.35 & -5.66 & 7.39 & 0.87 \\
\hline MALAYSIA & 1.72 & -3.63 & 3.78 & 2.52 & -4.73 & 9.42 & 0.68 & 2.85 & -4.53 & 11.80 & *** & 2.81 & -5.86 & 6.91 & 0.12 \\
\hline PHILIPPINES & 1.41 & -3.26 & 3.46 & 2.09 & -5.28 & 4.80 & 0.12 & 2.19 & -6.01 & 3.98 & $* * *$ & 2.46 & -4.84 & 6.80 & $* *$ \\
\hline SINGAPORE & 1.30 & -2.89 & 3.00 & 2.13 & -3.58 & 5.92 & 0.09 & 1.94 & -3.30 & 7.00 & 0.24 & 2.35 & -3.84 & 7.62 & $* *$ \\
\hline THAILAND & 1.78 & -3.49 & 4.74 & 2.18 & -4.05 & 7.52 & 0.31 & 2.05 & -3.51 & 5.96 & 0.69 & 5.71 & -6.33 & 10.42 & **** \\
\hline GREECE & 1.59 & -3.32 & 3.62 & 2.20 & -4.99 & 5.50 & $* *$ & 2.23 & -6.02 & 3.85 & **** & 1.89 & -5.53 & 4.02 & 0.26 \\
\hline FINLAND & 1.31 & -2.79 & 2.82 & 2.14 & -4.85 & 4.36 & $* * *$ & 2.42 & -5.59 & 4.50 & $* * *$ & 1.71 & -4.81 & 3.31 & 0.74 \\
\hline HOLLAND & 1.16 & -2.42 & 2.46 & 1.89 & -5.00 & 3.38 & $* * *$ & 1.82 & -5.21 & 2.68 & $* * *$ & 1.32 & -3.15 & 2.50 & 0.29 \\
\hline NORWAY & 1.00 & -2.29 & 2.18 & 1.99 & -4.95 & 4.57 & $* * *$ & 2.11 & -5.23 & 3.92 & $* * *$ & 1.61 & -4.73 & 3.88 & 0.08 \\
\hline SPAIN & 1.03 & -2.13 & 2.29 & 1.61 & -4.74 & 3.78 & $* *$ & 1.67 & -6.03 & 3.06 & $* * *$ & 1.16 & $\begin{array}{l}-3.09 \\
\end{array}$ & 2.54 & 0.58 \\
\hline SWEDEN & 0.98 & -2.16 & 2.00 & 1.69 & -3.61 & 3.17 & **** & 1.61 & -4.07 & 2.09 & $* * *$ & 1.22 & -2.79 & 2.09 & 0.31 \\
\hline TURKEY & 2.49 & -5.75 & 5.82 & 3.73 & -9.25 & 8.78 & **** & 4.29 & -10.99 & 9.86 & $* * *$ & 3.12 & -8.23 & 7.98 & 0.65 \\
\hline CANADA & 0.71 & -1.63 & 1.49 & 1.32 & -3.32 & 2.29 & **** & 1.19 & -3.18 & 2.46 & $* *$ & 0.94 & -1.90 & 2.13 & $* *$ \\
\hline FRANCE & 0.90 & $\begin{array}{l}-1.00 \\
-2.02\end{array}$ & $\begin{array}{l}2.45 \\
2.01\end{array}$ & 1.38 & $\begin{array}{l}-3.34 \\
-3.34 \\
-10\end{array}$ & 2.94 & ***: & 1.51 & $\begin{array}{l}-0.10 \\
-4.29\end{array}$ & 2.55 & $* * *$ & 0.99 & $\begin{array}{l}-3.08 \\
-3.08\end{array}$ & 2.20 & 0.69 \\
\hline ITALY & 1.26 & -2.61 & 2.88 & 2.02 & -4.33 & 4.96 & $* *$ & 2.08 & -5.63 & 3.22 & $* * *$ & 1.39 & -3.91 & 2.86 & 0.33 \\
\hline GERMANY & 1.20 & -2.54 & 2.27 & 2.01 & -5.54 & 3.94 & ${ }^{* * *}$ & 2.05 & -5.68 & 3.51 & ***** & 1.58 & -4.32 & 3.35 & 0.38 \\
\hline JAPAN & 0.93 & -1.99 & 2.20 & 1.37 & -3.00 & 3.76 & 0.24 & 1.18 & -2.55 & 3.03 & 0.61 & 1.25 & -3.22 & 3.56 & 0.25 \\
\hline UK & 0.86 & -1.90 & 1.86 & 1.29 & -3.13 & 3.00 & $* * *$ & 1.52 & -3.14 & 2.69 & $* * * *$ & 0.99 & -2.03 & 2.89 & 0.11 \\
\hline USA & 0.87 & -1.80 & 1.90 & 1.72 & -3.32 & 3.70 & $* * *$ & 1.31 & -2.80 & 4.02 & 0.23 & 1.01 & -2.13 & 2.18 & 0.13 \\
\hline ARGENTINA & 1.60 & -4.31 & 3.41 & 4.58 & -10.44 & 8.51 & $* * *$ & 3.32 & -10.44 & 7.41 & ** & 2.23 & -4.15 & 6.09 & 0.12 \\
\hline BRAZIL & 2.13 & -4.84 & 4.31 & 7.67 & -10.09 & 12.19 & $* * *$ & 3.89 & -10.08 & 7.66 & $* *$ & 2.56 & -5.19 & 6.72 & 0.20 \\
\hline CHILE & 1.03 & -2.24 & 2.42 & 2.25 & -5.04 & 4.34 & **** & 1.58 & -5.04 & 2.53 & 0.16 & 1.28 & -2.86 & 3.36 & 0.09 \\
\hline COLOMBIA & 0.83 & -2.01 & 2.17 & 1.10 & -3.74 & 2.02 & $* *$ & 0.91 & -3.11 & 1.88 & ${ }_{* *}^{0.10}$ & 0.88 & $\begin{array}{l}-2.08 \\
-2.08\end{array}$ & $\begin{array}{l}2.47 \\
2.47\end{array}$ & 0.40 \\
\hline MEXICO & 1.35 & -2.78 & 3.23 & 3.21 & $\begin{array}{l}-0.14 \\
-6.05\end{array}$ & 8.43 & ***** & 2.58 & -5.57 & 6.40 & $* *$ & 1.80 & -3.76 & 4.59 & 0.26 \\
\hline PERU & $\begin{array}{l}.001 \\
1.01\end{array}$ & $\begin{array}{l}-2.10 \\
-2.15\end{array}$ & $\begin{array}{l}0.33 \\
2.33\end{array}$ & $\begin{array}{l}0.93 \\
1.93\end{array}$ & $\begin{array}{l}-0.05 \\
-5.64 \\
-10\end{array}$ & $\begin{array}{l}0.45 \\
3.84\end{array}$ & $* * *$ & $\begin{array}{l}.300 \\
1.63\end{array}$ & $\begin{array}{l}-5.51 \\
-5.11 \\
-10\end{array}$ & $\begin{array}{l}\text { l.40 } \\
3.78\end{array}$ & $* *$ & $\begin{array}{l}1.00 \\
1.21\end{array}$ & $\begin{array}{l}-2.47 \\
-.110 \\
-10\end{array}$ & $\begin{array}{l}4.59 \\
3.51\end{array}$ & $\begin{array}{l}{ }^{*} .20 \\
* *\end{array}$ \\
\hline VENEZUELA & 1.55 & -3.98 & 3.48 & 2.63 & -7.51 & 3.85 & $* * *$ & 2.03 & -6.65 & 3.08 & $* *$ & 1.85 & -4.55 & 3.67 & 0.32 \\
\hline CZECH REPUBLIC & 0.94 & -2.30 & 2.10 & 1.61 & -3.70 & 2.81 & ***** & 1.83 & -3.93 & 3.13 & **** & 0.98 & -2.21 & 2.06 & 0.96 \\
\hline ESTONIA & 1.84 & -4.00 & 4.54 & 3.04 & -10.49 & 7.01 & $* * *$ & 3.54 & $\begin{array}{l}-10.49 \\
-\end{array}$ & 8.64 & ***** & 2.37 & -6.98 & 5.74 & 0.37 \\
\hline HUNGARY & 1.63 & -3.48 & 3.48 & 3.65 & -10.51 & 9.32 & ***** & 3.61 & -10.76 & 5.91 & $* * * *$ & 2.18 & -6.02 & 3.47 & 0.48 \\
\hline POLAND & 1.35 & -3.02 & 3.03 & 2.61 & -5.74 & 6.00 & ***** & 2.45 & -6.27 & 4.66 & $* * *$ & 1.98 & -5.00 & 3.75 & 0.06 \\
\hline RUSSIA & 2.49 & -5.10 & 6.48 & 4.75 & -12.49 & 13.85 & ${ }^{* * *}$ & 9.74 & -17.49 & 16.71 & $* * *$ & 3.46 & -7.35 & 8.56 & 0.31 \\
\hline SLOVAKIA & 0.97 & -2.49 & 2.38 & 0.97 & -3.04 & 2.68 & 0.94 & 1.19 & -3.10 & 2.52 & *** & 1.14 & -3.07 & 2.90 & 0.47 \\
\hline UKRAINE & 2.07 & -5.18 & 5.42 & 4.37 & -10.94 & 8.99 & $* * * *$ & 3.27 & -11.56 & 8.37 & 0.16 & 2.37 & -6.24 & 8.56 & 0.96 \\
\hline
\end{tabular}

Notes: Turmoil is defined as those observations in the 5 th and 95th percentiles. Mean is the average of one day percent returns in absolute values. The Kolmogorov Smirnov Test evaluates whether the frequency distribution on days of turmoil in the corresponding emerging market is different from the frequency distribution on all other days. 5th and 95th percentiles report the the values of stock market returns at those percentiles. The sample extends from January 1,1997 to August 31,1999. ${ }^{\star \star *},{ }^{* *}$ represent the significance of the Kolmogorov Smirnov Test at the 1 and 5 percent level respectively. 
Table 6

Weak-Form Globalization of Turmoil

Regional and World Effects

\begin{tabular}{|c|c|c|c|}
\hline \multirow{2}{*}{ REGIONS } & \multicolumn{3}{|c|}{ Percentage of Countries with Anomalous Returns when Turmoil in } \\
\cline { 2 - 4 } & BRAZIL & RUSSIA & THAILAND \\
\hline Asia & 14 & 29 & 67 \\
Europe & 100 & 100 & 0 \\
G7 & 83 & 67 & 17 \\
Latin America & 100 & 86 & 0 \\
Transition Economies & 86 & 73 & 18 \\
World & 76 & 73 & \\
\hline
\end{tabular}

Notes: A turmoil is defined as those observations in the 5th and 95th percentiles.

An anomalous return is interpreted as a change in the distribution of returns in country $j$ on days of turmoil in country $i$. 
Table 7

Financial Turmoil in Emerging Markets and Financial Centers: How Does It Spread?

\begin{tabular}{|c|c|c|c|c|c|c|c|c|c|c|c|c|c|c|c|c|c|c|c|c|c|c|c|c|c|c|c|}
\hline \multirow{4}{*}{ COUNTRIES } & \multicolumn{27}{|c|}{ Empirical Distribution of Stock Market Returns } \\
\hline & \multicolumn{3}{|c|}{ ON ALL DAYS } & \multirow{2}{*}{\multicolumn{8}{|c|}{$\begin{array}{l}\text { ON DAYS OF TURMOLL IN BRAZIL } \\
\text { With Financial center }\end{array}$}} & \multirow{2}{*}{\multicolumn{8}{|c|}{ 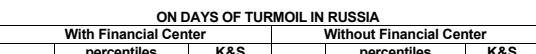 }} & \multicolumn{8}{|c|}{$\begin{array}{l}\text { ON DAYS OF TURMOLL IN THALLAND } \\
\text { With Financial Conter }\end{array}$} \\
\hline & \multirow{2}{*}{$\begin{array}{c}\text { mean } \\
1.40\end{array}$} & \multirow{2}{*}{\multicolumn{2}{|c|}{$\begin{array}{c}\text { percentiles } \\
5 \text { th }\end{array}$}} & & & & & & \multirow{2}{*}{\multicolumn{3}{|c|}{ 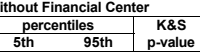 }} & \multirow{2}{*}{\multicolumn{3}{|c|}{\begin{tabular}{|l} 
Wuth Financlace \\
percentiles \\
5 th
\end{tabular}}} & & & \multirow{2}{*}{\multicolumn{3}{|c|}{\begin{tabular}{|c|c|} 
percentiles & $\begin{array}{c}\text { K8S } \\
\text { p-value }\end{array}$ \\
5 th & 95 th
\end{tabular}}} & \multirow{2}{*}{\multicolumn{3}{|c|}{\begin{tabular}{l|l} 
& With Financial Cen \\
mean & percentiles \\
\cline { 2 - 3 } & S
\end{tabular}}} & \multirow{2}{*}{ 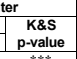 } & \multirow{2}{*}{ mean } & \multirow{2}{*}{\multicolumn{3}{|c|}{$\begin{array}{l}\text { ithout Financial Ce } \\
\text { percentiles } \\
\text { 5th } 95 \text { th }\end{array}$}} \\
\hline & & & & mean & 5 th & 95 th & $\begin{array}{c}\text { K\&s } \\
\text { p-value } \\
\text { pula }\end{array}$ & & & & & & & & 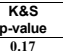 & mean & & & & & & & & & & & \\
\hline $\begin{array}{l}\text { INDONESIA } \\
\text { INONG }\end{array}$ & $\begin{array}{l}7.40 \\
1.62\end{array}$ & -3.394 & 4.51 & $\begin{array}{l}2.41 \\
2.50\end{array}$ & -5.15 & 6.77 & $\underset{n * *}{0.32}$ & $\begin{array}{l}2.00 \\
2.00\end{array}$ & $\begin{array}{lll}-4.38 \\
-4.02\end{array}$ & $\begin{array}{l}3.53 \\
6.26\end{array}$ & 0.34 & $\begin{array}{l}2.05 \\
2.32\end{array}$ & -5.15 & 6.47 & $\begin{array}{l}0.17 \\
0.30\end{array}$ & $\begin{array}{l}1.78 \\
1.79\end{array}$ & $\begin{array}{l}-3.10 \\
-3.44\end{array}$ & $\begin{array}{l}6.95 \\
5.83\end{array}$ & ${ }_{0.56}^{0.11}$ & $\begin{array}{l}2.45 \\
2.89\end{array}$ & $\begin{array}{l}-4.52 \\
-5.03\end{array}$ & 8.00 & 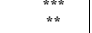 & $\begin{array}{l}1.96 \\
2.13\end{array}$ & -4.28 & $\begin{array}{l}5.55 \\
5.75\end{array}$ & $\begin{array}{l}0.13 \\
0.72\end{array}$ \\
\hline $\begin{array}{c}\text { KKREAA } \\
\text { MALAYSIA }\end{array}$ & $\begin{array}{l}1.196 \\
1.72\end{array}$ & -4.63 & $\begin{array}{l}5.32 \\
3.78\end{array}$ & 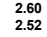 & 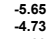 & 9.42 & $\begin{array}{l}0.37 \\
0.68\end{array}$ & 2.23 & - -5.65 & 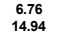 & 0.92 & $\begin{array}{l}2.88 \\
2.85\end{array}$ & -4.453 & 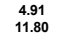 & $\begin{array}{c}0.49 \\
k \neq\end{array}$ & 年.74 2.14 & - $\begin{array}{l}-3.94 \\
-4.68\end{array}$ & 5.08 & 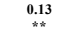 & $\begin{array}{l}2.35 \\
2.81\end{array}$ & -.5.66 -.56 & $\begin{array}{l}7.39 \\
6.91\end{array}$ & $\begin{array}{l}0.87 \\
0.12\end{array}$ & $\begin{array}{l}2.00 \\
2.15\end{array}$ & . -5.66 & $\begin{array}{l}7.39 \\
4.36\end{array}$ & 0.69 \\
\hline 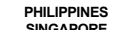 & 1.41 & $\begin{array}{l}-3.26 \\
-3.00\end{array}$ & 3.46 & 2.09 & $\begin{array}{l}-5.28 \\
-.5280 \\
\end{array}$ & $\begin{array}{l}3.86 \\
4.80\end{array}$ & 0.12 & 1.68 & - 4.600 & 3.11 & 0.12 & 2.19 & -6.01 & 3.98 & ***** & 1.79 & -4.49 & $\begin{array}{l}3.90 \\
3.95\end{array}$ & 0.58 & 2.46 & -4.84 & 6.80 & 等. & $\begin{array}{l}2.15 \\
1.99\end{array}$ & $\begin{array}{l}-4.403 \\
-4.43\end{array}$ & $\begin{array}{l}4.36 \\
5.97\end{array}$ & $\begin{array}{l}0.48 \\
0.34\end{array}$ \\
\hline $\begin{array}{l}\text { IISGAPORE } \\
\text { THAALAND }\end{array}$ & $\begin{array}{l}\text { 1.30 } \\
1.78\end{array}$ & $\begin{array}{l}-2.289 \\
-{ }_{-3.49}\end{array}$ & $\begin{array}{l}3.000 \\
4.74\end{array}$ & $\begin{array}{l}2.13 \\
2.18\end{array}$ & $\begin{array}{l}-3.58 \\
-4.05 \\
\text {. }\end{array}$ & $\begin{array}{l}5.92 \\
7.52\end{array}$ & $\begin{array}{l}0.09 \\
0.31\end{array}$ & $\begin{array}{l}\begin{array}{l}1.73 \\
1.97\end{array} \\
\text {. }\end{array}$ & $\begin{array}{l}-3.21 \\
-3.95 \\
-x^{2}\end{array}$ & $\begin{array}{l}4.92 \\
6.36\end{array}$ & $\begin{array}{l}0.36 \\
0.77 \\
0.77\end{array}$ & $\begin{array}{l}\begin{array}{l}1.94 \\
2.05\end{array} \\
\end{array}$ & $\begin{array}{l}-3.30 \\
-3.51\end{array}$ & $\begin{array}{l}7.700 \\
5.96\end{array}$ & $\begin{array}{l}l_{0.64}^{2.42} \\
0.69\end{array}$ & 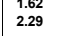 & $\begin{array}{l}-3.3 .30 \\
-3.47\end{array}$ & $\begin{array}{l}6.22 \\
7.44\end{array}$ & 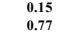 & $\begin{array}{l}2.35 \\
5.71\end{array}$ & 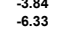 & $\begin{array}{l}7.62 \\
10.42\end{array}$ & 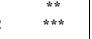 & $\begin{array}{l}1.80 \\
5.59\end{array}$ & $\begin{array}{l}-.382 \\
-6.76 \\
-6.76\end{array}$ & $\begin{array}{l}5.56 \\
10.74\end{array}$ & 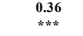 \\
\hline GREECE & 1.59 & $\begin{array}{l}-3.32 \\
-3.72\end{array}$ & 3.62 & 2.20 & -4.99 & 5.50 & $* *$ & 1.64 & -4.00 & 3.47 & 0.13 & 2.23 & - -6.02 & $\begin{array}{l}3.85 \\
\end{array}$ & $* * * *$ & 1.71 & -3.86 & 3.95 & 0.70 & 1.89 & .5 .53 & 4.02 & 0.26 & 1.76 & -5.54 & 3.67 & 0.31 \\
\hline $\begin{array}{l}\begin{array}{l}\text { FINLAND } \\
\text { HOLLAND }\end{array} \\
\text { HoLA }\end{array}$ & $\begin{array}{l}1.31 \\
1.16\end{array}$ & $\begin{array}{l}-2.79 \\
-2.42\end{array}$ & $\begin{array}{l}2.82 \\
2.46\end{array}$ & $\begin{array}{l}2.14 \\
1.89\end{array}$ & $\begin{array}{l}-4.85 \\
-5.00 \\
\end{array}$ & $\begin{array}{l}4.36 \\
3.38\end{array}$ & 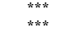 & $\begin{array}{l}\text { 吕9 } \\
1.57\end{array}$ & $\begin{array}{l}-4.49 \\
-2.78\end{array}$ & $\begin{array}{l}\begin{array}{l}2.83 \\
2.92\end{array} \\
2.9\end{array}$ & 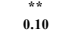 & $\begin{array}{l}2.242 \\
1.82\end{array}$ & $\begin{array}{l}-5.599 \\
-5.21\end{array}$ & $\begin{array}{l}4.450 \\
2.68\end{array}$ & 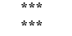 & 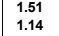 & $\begin{array}{l}-3.17 \\
-2.53 \\
-1.7\end{array}$ & $\begin{array}{l}3.95 \\
1.86\end{array}$ & $\begin{array}{l}0.011 \\
0.27\end{array}$ & $\begin{array}{l}\begin{array}{l}1.71 \\
1.32\end{array} \\
\end{array}$ & $\begin{array}{l}-4.81 \\
-3.15\end{array}$ & $\begin{array}{l}3.31 \\
2.50\end{array}$ & $\begin{array}{l}0.74 \\
0.29\end{array}$ & $\begin{array}{l}\underbrace{}_{1.38} \\
1.24\end{array}$ & $\begin{array}{l}-2.26 \\
-x_{-1.98}\end{array}$ & $\begin{array}{l}3.96 \\
2.93\end{array}$ & $\begin{array}{l}0.47 \\
0.49\end{array}$ \\
\hline $\begin{array}{l}\text { NORWAY } \\
\text { SPANA }\end{array}$ & $\begin{array}{l}1.00 \\
1.03\end{array}$ & $\begin{array}{l}-2.29 \\
-2.213\end{array}$ & $\begin{array}{l}2.18 \\
2.29\end{array}$ & $\begin{array}{l}1.99 \\
161\end{array}$ & $\begin{array}{l}-4.95 \\
-474\end{array}$ & $\begin{array}{l}4.57 \\
3.78\end{array}$ & t.t.t. & $\begin{array}{l}1.66 \\
1.43\end{array}$ & $\begin{array}{l}-4.04 \\
-4.83\end{array}$ & $\begin{array}{l}3.47 \\
2.49\end{array}$ & **t. & $\begin{array}{l}2.11 \\
1.67\end{array}$ & $\begin{array}{l}-5.23 \\
-6.03 \\
-6.03\end{array}$ & $\begin{array}{l}3.92 \\
3.06\end{array}$ & 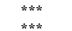 & $\begin{array}{l}1.49 \\
0.86\end{array}$ & $\begin{array}{l}-2.96 \\
-x_{178}\end{array}$ & $\begin{array}{l}3.89 \\
1.96\end{array}$ & $\begin{array}{l}0.07 \\
0.68\end{array}$ & $\begin{array}{l}1.61 \\
1.16\end{array}$ & $\begin{array}{l}-4.73 \\
-3.39\end{array}$ & $\begin{array}{l}3.88 \\
2.54\end{array}$ & $\begin{array}{l}0.08 \\
0.58\end{array}$ & $\begin{array}{l}1.31 \\
0.99\end{array}$ & $\begin{array}{l}-2.77 \\
-2.30\end{array}$ & $\begin{array}{l}3.51 \\
.30\end{array}$ & 0.19 \\
\hline & & & & & & & $k * * *$ & 0.71 & -1.81 & & 0.98 & & & 2.46 & & & -2.20 & 2.03 & & & -1.90 & & & & & & \\
\hline $\begin{array}{l}\text { FRANCE } \\
\text { DAYY }\end{array}$ & 0.90 & -2.02 & 2.01 & 1.38 & 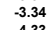 & 2.94 & $* * *$ & $\begin{array}{l}1.18 \\
1.83\end{array}$ & $\begin{aligned}-2.95 \\
-410\end{aligned}$ & $\begin{array}{l}2.20 \\
3.38\end{array}$ & 0.19 & 1.51 & $\begin{array}{l}-4.29 \\
-5.53\end{array}$ & $\begin{array}{l}2.55 \\
.320\end{array}$ & *n*** & 0.84 & -2.08 & 1.30 & 0.39 & 0.99 & $\begin{array}{r}-3.08 \\
-3.01\end{array}$ & $\begin{array}{l}2.20 \\
2.28\end{array}$ & 0.69 & 0.90 & $\begin{array}{r}-2.03 \\
-2.233\end{array}$ & 2.34 & 0.99 \\
\hline $\begin{array}{l}\text { IIALY } \\
\text { GERMANY }\end{array}$ & $\begin{array}{l}1.26 \\
1.20\end{array}$ & $\begin{array}{l}-2.261 \\
-2.54\end{array}$ & $\begin{array}{l}2.88 \\
2.27\end{array}$ & $\begin{array}{l}2.02 \\
2.01\end{array}$ & $\begin{array}{l}-4.33 \\
-5.54 \\
\text {. }\end{array}$ & $\begin{array}{l}4.96 \\
3.94\end{array}$ & 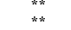 & $\begin{array}{l}1.83 \\
1.52\end{array}$ & $\begin{array}{l}-4.49 \\
-3.55 \\
\end{array}$ & $\begin{array}{l}\begin{array}{l}3.38 \\
2.15\end{array} \\
2.5\end{array}$ & $\begin{array}{l}0.11 \\
0.41\end{array}$ & $\begin{array}{l}2.08 \\
2.05\end{array}$ & $\begin{array}{l}-5.63 \\
-5.68\end{array}$ & $\begin{array}{l}3.22 \\
3.51\end{array}$ & 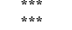 & $\begin{array}{l}1.46 \\
1.09\end{array}$ & $\begin{array}{l}-2.2 .90 \\
-{ }_{-2.31}\end{array}$ & $\begin{array}{l}3.05 \\
2.10\end{array}$ & $\begin{array}{l}0.23 \\
0.31\end{array}$ & $\begin{array}{l}\text {.39 } \\
1.58\end{array}$ & $\begin{array}{l}-3.391 \\
-4.32\end{array}$ & $\begin{array}{l}2.86 \\
3.35\end{array}$ & $\begin{array}{l}0.33 \\
0.38\end{array}$ & $\begin{array}{l}1.16 \\
1.44\end{array}$ & $\begin{array}{l}-2.233 \\
-2.58\end{array}$ & $\begin{array}{l}2.78 \\
3.62\end{array}$ & $\begin{array}{l}0.10 \\
0.82\end{array}$ \\
\hline $\begin{array}{l}\text { JAPAN } \\
\text { UKK }\end{array}$ & 0.93 & $\begin{array}{l}-1.99 \\
-190\end{array}$ & $\begin{array}{l}2.20 \\
186\end{array}$ & 1.37 & $\begin{array}{l}-3.00 \\
-3.13 \\
-3\end{array}$ & $\begin{array}{l}3.76 \\
3.00\end{array}$ & 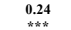 & 1.36 & $\begin{array}{l}-2.41 \\
-2.31\end{array}$ & $\begin{array}{l}3.87 \\
2.59\end{array}$ & 0.20 & $\begin{array}{l}1.18 \\
1.55\end{array}$ & $\begin{array}{l}-2.55 \\
-314\end{array}$ & 3.03 & $\begin{array}{l}0.61 \\
k \neq k\end{array}$ & $\begin{array}{l}1.05 \\
1.15\end{array}$ & $\begin{array}{l}-1.93 \\
-111\end{array}$ & $\begin{array}{l}3.06 \\
3.25\end{array}$ & 0.59 & 1.25 & $\begin{array}{l}-3.22 \\
-3.23\end{array}$ & $\begin{array}{l}3.56 \\
3.59\end{array}$ & 0.25 & 0.69 & $\begin{array}{l}-1.50 \\
-1.56\end{array}$ & 1.87 & $* *$ \\
\hline $\begin{array}{l}\text { USA } \\
\text { USA }\end{array}$ & $\begin{array}{l}0.80 \\
0.87\end{array}$ & $\begin{array}{l}-1.80 \\
-1.80\end{array}$ & $\begin{array}{l}1.1 .60 \\
1.90\end{array}$ & $\begin{array}{l}1.29 \\
1.72\end{array}$ & $\begin{array}{l}-3.13 \\
-3.32 \\
-3\end{array}$ & $\begin{array}{l}3.00 \\
3.70\end{array}$ & 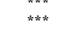 & $\begin{array}{l}\begin{array}{l}1.12 \\
0.93\end{array} \\
\end{array}$ & $\begin{array}{l}-2.13 \\
-1.77\end{array}$ & $\begin{array}{l}2.299 \\
1.68\end{array}$ & $\begin{array}{l}0.099 \\
0.19\end{array}$ & $\begin{array}{l}1.52 \\
1.31\end{array}$ & $\begin{array}{l}-2.80 \\
-2.80\end{array}$ & $\begin{array}{l}2.69 \\
4.02\end{array}$ & $\begin{array}{l}0.23 \\
0.23\end{array}$ & 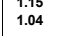 & $\begin{array}{l}-2.111 \\
-{ }_{-1.83}\end{array}$ & $\begin{array}{l}\begin{array}{l}2.355 \\
3.49\end{array} \\
\end{array}$ & $\begin{array}{l}l_{0.10}^{0.10} \\
0.79\end{array}$ & $\begin{array}{l}0.99 \\
1.01\end{array}$ & $\begin{array}{l}-2.23 \\
-2.13 \\
-2.3\end{array}$ & $\begin{array}{l}2.89 \\
2.18\end{array}$ & $\begin{array}{l}0.11 \\
0.13\end{array}$ & $\begin{array}{l}0.89 \\
0.99\end{array}$ & $\begin{array}{l}-1.65 \\
-2.11\end{array}$ & $\begin{array}{l}2.73 \\
2.16\end{array}$ & $\begin{array}{l}0.40 \\
0.16\end{array}$ \\
\hline $\begin{array}{l}\text { ARGENTINA } \\
\text { BEAZIL }\end{array}$ & $\begin{array}{l}1.60 \\
2.13\end{array}$ & $\begin{array}{l}-4.31 \\
-4.84\end{array}$ & $\begin{array}{l}3.41 \\
4.31\end{array}$ & $\begin{array}{l}4.58 \\
7.67\end{array}$ & $\begin{array}{l}-10.44 \\
-10.09 \\
\end{array}$ & $\begin{array}{l}8.51 \\
1.219\end{array}$ & 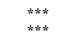 & $\begin{array}{l}3.48 \\
6.68\end{array}$ & $\begin{array}{l}-8.82 \\
-9.69\end{array}$ & $\begin{array}{l}6.55 \\
8.81\end{array}$ & 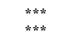 & $\begin{array}{l}3.32 \\
3.89\end{array}$ & $\begin{array}{l}-10.44 \\
-10.08 \\
-108\end{array}$ & $\begin{array}{l}7.41 \\
7.66\end{array}$ & 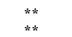 & $\begin{array}{l}2.63 \\
3.24\end{array}$ & $\begin{array}{l}-4.85 \\
-8.86\end{array}$ & $\begin{array}{l}8.49 \\
10.79\end{array}$ & $\begin{array}{l}0.13 \\
0.51\end{array}$ & $\begin{array}{l}2.23 \\
2.56\end{array}$ & $\begin{array}{l}-4.15 \\
-.519\end{array}$ & $\begin{array}{l}6.09 \\
6.72\end{array}$ & $\begin{array}{l}0.122 \\
0.20\end{array}$ & $\begin{array}{l}2.18 \\
2.57\end{array}$ & $\begin{array}{l}-4.74 \\
-.512\end{array}$ & $\begin{array}{l}6.53 \\
7.20\end{array}$ & $\begin{array}{l}0.33 \\
0.24\end{array}$ \\
\hline BRAZIL & $\begin{array}{l}2.1 .13 \\
1.03\end{array}$ & $\begin{array}{l}-4.24 \\
-2.24\end{array}$ & $\begin{array}{l}4.31 \\
2.42 \\
\end{array}$ & 2.25 & 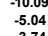 & $\begin{array}{l}12.39 \\
4.34\end{array}$ & 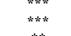 & $\begin{array}{l}6.68 \\
1.95\end{array}$ & $\begin{array}{l}-9.969 \\
-3.87 \\
\end{array}$ & $\begin{array}{l}8.81 \\
4.08\end{array}$ & 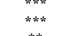 & $\begin{array}{l}3.59 \\
1.58\end{array}$ & $\begin{array}{l}-10.008 \\
-5.04\end{array}$ & $\begin{array}{l}7.56 \\
2.53\end{array}$ & 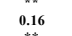 & $\begin{array}{l}3.24 \\
1.27\end{array}$ & $\begin{array}{l}-8.86 \\
-3.07 \\
-3.07\end{array}$ & $\begin{array}{l}1.7 .79 \\
3.73\end{array}$ & $\begin{array}{l}0.01 \\
0.63\end{array}$ & $\begin{array}{l}2.256 \\
1.28\end{array}$ & $\begin{array}{l}-.5 .96 \\
-2.86 \\
\end{array}$ & $\begin{array}{l}\begin{array}{l}6.72 \\
3.36\end{array} \\
\end{array}$ & $\begin{array}{l}0_{0.20} \\
0.09\end{array}$ & $\begin{array}{l}2.57 \\
1.31\end{array}$ & $\begin{array}{l}-2.59 \\
-2.99 \\
-2.12\end{array}$ & $\begin{array}{l}7.50 \\
3.53\end{array}$ & $\begin{array}{l}0.24 \\
0.28\end{array}$ \\
\hline COLOMBIA & $\begin{array}{l}0.83 \\
1.35\end{array}$ & $\begin{array}{l}-2.01 \\
-2.78\end{array}$ & $\begin{array}{l}2.17 \\
3.23\end{array}$ & $\begin{array}{l}1.10 \\
3.21\end{array}$ & $\begin{array}{l}-3.74 \\
-6.05\end{array}$ & $\begin{array}{l}2.02 \\
8.43\end{array}$ & 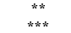 & $\begin{array}{l}1.14 \\
2.19\end{array}$ & $\begin{array}{l}-3.97 \\
-3.45\end{array}$ & $\begin{array}{l}2.23 \\
5.12\end{array}$ & $\begin{array}{l}* . * \\
0.12\end{array}$ & $\begin{array}{l}0.911 \\
2.58\end{array}$ & $\begin{array}{l}-.3 .11 \\
-5.57\end{array}$ & $\begin{array}{l}1.88 \\
6.40\end{array}$ & $\begin{array}{c}k * \\
k * \\
k \neq\end{array}$ & $\begin{array}{l}0.85 \\
191\end{array}$ & $\begin{array}{l}-3.79 \\
-3.375\end{array}$ & $\begin{array}{l}1.94 \\
5.89\end{array}$ & $\begin{array}{l}0.18 \\
0.50\end{array}$ & $\begin{array}{l}0.88 \\
1.80\end{array}$ & $\begin{array}{l}-2.08 \\
-3.36\end{array}$ & $\begin{array}{l}2.47 \\
4.59\end{array}$ & $\begin{array}{l}0.40 \\
0.26\end{array}$ & $\begin{array}{l}0.91 \\
1.56\end{array}$ & $\begin{array}{l}-1.98 \\
-3.66\end{array}$ & $\begin{array}{l}2.51 \\
.62\end{array}$ & 0.37 \\
\hline $\begin{array}{c}\text { PERU } \\
\text { VENERU }\end{array}$ & $\begin{array}{l}1.01 \\
1.55\end{array}$ & $\begin{array}{l}-2.15 \\
-3.98\end{array}$ & $\begin{array}{l}2.33 \\
2.34\end{array}$ & $\begin{array}{l}1.93 \\
263\end{array}$ & $\begin{array}{l}-5.64 \\
-.5 .51 \\
\text { nat }\end{array}$ & $\begin{array}{l}3.84 \\
3.85\end{array}$ & * & $\begin{array}{l}1.44 \\
2.33\end{array}$ & $\begin{array}{l}-5.34 \\
-.79 \\
-7.9\end{array}$ & $\begin{array}{l}3.37 \\
3.39\end{array}$ & 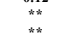 & $\begin{array}{l}1.63 \\
203\end{array}$ & $\begin{array}{l}-5.111 \\
-6.65\end{array}$ & $\begin{array}{l}3.78 \\
3.788\end{array}$ & *nt* & $\begin{array}{l}1.25 \\
1.50\end{array}$ & $\begin{array}{l}-2.283 \\
-x_{4-49}\end{array}$ & $\begin{array}{l}3.84 \\
3.307\end{array}$ & $\begin{array}{l}0.47 \\
0.44\end{array}$ & $\begin{array}{l}1.21 \\
1.25\end{array}$ & $\begin{array}{l}-2.47 \\
-2.45\end{array}$ & $\begin{array}{l}3.51 \\
3.67\end{array}$ & 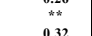 & $\begin{array}{l}1.116 \\
1.95\end{array}$ & $\begin{array}{l}-2.29 \\
-2.47\end{array}$ & $\begin{array}{l}2.65 \\
4_{412}\end{array}$ & $\begin{array}{l}* * \\
0 * \\
012\end{array}$ \\
\hline CZECH & & & 2.10 & & -3.70 & & $* * *$ & & -3.711 & 2.85 & $* *$ & 1.83 & & 3.13 & $* * * *$ & 1.43 & & 3.07 & 0.06 & & -2.21 & & 0.96 & & & & \\
\hline & $\begin{array}{l}2.4 \\
0.9\end{array}$ & $\begin{array}{l}-5.100 \\
-2.49\end{array}$ & $\begin{array}{l}6.48 \\
2.38\end{array}$ & $\begin{array}{l}4.75 \\
0.97\end{array}$ & & $\begin{array}{l}\begin{array}{l}13.85 \\
2.68\end{array} \\
2.68\end{array}$ & 0.94 & $\begin{array}{l}3.58 \\
0.91\end{array}$ & -6.5 & 8.4 & $\begin{array}{l}0.1 \\
0.9\end{array}$ & $\begin{array}{l}9.74 \\
1.19\end{array}$ & & 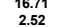 & * & & & & 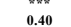 & & & & & & & & $\begin{array}{l}18 \\
23\end{array}$ \\
\hline UKRAINE & 2.07 & -5.18 & 5.42 & 4.37 & -10.94 & 8.99 & ${ }_{* * * *}$ & 3.72 & -10.94 & 8.99 & 0.08 & 3.27 & -11.56 & 8.37 & 0.16 & 3.04 & -7.04 & 8.83 & 0.19 & 2.37 & -6.24 & 8.56 & 0.96 & 1.65 & - -3.68 & 8.28 & 0.99 \\
\hline
\end{tabular}

Notes: Turmoil is defined as those observations in the 5 th and 95 th percentiles. Mean is the average of one day percent returns in absolute values. The Kolmogorov Smirnov Test evaluates whether the frequency distribution on days of turmoil in the corresponding emerging
(with or without turmoil in a financial center) is different from the frequency distribution on all other days. 5 th and 95 th percentiles report the the values of stock market returns at those percentiles. The sample extends from January 1,1997 to August 31,1999 . $* x, * *$ 
Table 8

Weak-Form Globalization of Turmo il

Regional and World Effects

\begin{tabular}{|c|c|c|c|c|c|c|c|c|c|}
\hline \multirow{3}{*}{ REGIONS } & \multicolumn{9}{|c|}{ Percentage of Countries with Anomalous Returns when Turmoil in } \\
\hline & \multicolumn{3}{|c|}{ BRAZIL } & \multicolumn{3}{|c|}{ RUSSIA } & \multicolumn{3}{|c|}{ THAILAND } \\
\hline & $\begin{array}{l}\text { With Financial } \\
\text { Center }\end{array}$ & $\begin{array}{c}\text { Without } \\
\text { Financial } \\
\text { Center }\end{array}$ & $\underset{p \text {-value }}{W}$ & $\begin{array}{l}\text { With Financial } \\
\text { Center }\end{array}$ & $\begin{array}{c}\text { Without } \\
\text { Financial } \\
\text { Center }\end{array}$ & $\underset{p \text {-value }}{W}$ & $\begin{array}{l}\text { With Financial } \\
\text { Center }\end{array}$ & $\begin{array}{c}\text { Without } \\
\text { Financial } \\
\text { Center }\end{array}$ & $\underset{p \text {-value }}{w}$ \\
\hline Asia & 14 & 0 & & 29 & 14 & & 67 & 0 & \\
\hline Europe & 100 & 29 & & 100 & 0 & & 0 & 0 & \\
\hline G7 & 83 & 0 & & 67 & 0 & & 17 & 14 & \\
\hline Latin America & 100 & 83 & & 86 & 0 & & 14 & 14 & \\
\hline Transition Economies & 86 & 14 & & 83 & 33 & & 0 & 0 & \\
\hline World & 76 & 24 & & 73 & 12 & & 18 & 6 & \\
\hline Wilcoxon Statistic (W) & 1320 & 891 & 0.00 & 1452 & 759 & 0.00 & 1188 & 1023 & 0.00 \\
\hline
\end{tabular}

Notes: The Financial Center is respectively USA for Brazil, Germany for Russia and Japan for Thailand. Turmoil is defined as those observations in the 5th and 95th percentiles. An anomalous return is interpreted as a change in the distribution of returns in country j on days of turmoil in country i. 
Table 9

\section{Strong-Form Globalization Multinomial Logit Estimation}

$$
P(y=i)=\exp \left(x^{\prime} \beta_{i}\right) /\left(1+\sum_{i=1}^{2} \exp \left(x^{\prime} \beta_{i}\right)\right)
$$

\begin{tabular}{|c|c|c|c|}
\hline \multirow{2}{*}{ Degree of Globalization } & \multicolumn{3}{|c|}{ Coefficients } \\
\cline { 2 - 4 } & TURMOIL IN GERMANY & TURMOIL IN JAPAN & TURMOII IN USA \\
\hline Medium & $2.51^{\star * *}$ & $1.78^{\star * *}$ & $1.25^{\star * *}$ \\
& $(7.88)$ & $(5.49)$ & $(3.74)$ \\
\hline High & & & $2.45^{\star * *}$ \\
& $4.71^{* \star *}$ & $2.56^{* \star *}$ & $(6.85)$ \\
\hline Pseudo R2 & $(7.14)$ & $(5.72)$ & $\mathbf{0 . 1 0}$ \\
\hline Number of Observations & $\mathbf{0 . 1 9}$ & $\mathbf{0 . 0 8}$ & $\mathbf{6 9 4}$ \\
\hline
\end{tabular}

Notes: Numbers in parentheses represent z statistics. ${ }^{* * *}, * *{ }^{*}$ represents the significance of the coefficient at the 1,5 and 10 percent levels. Turmoil is defined as those observations in the 5th and 95th percentiles. The left-hand-side variable captures the degree of globalization. There are three possible degrees of globalization: Low ( when less than 25 percent of the countries in the sample experience turmoil), medium (when more than 25 percent but less than 50 percent of the countries experience turmoil), high ( when 50 percent or more of all countries in the sample experience turmoil). In order to be able to estimate our model, coefficients for the low globalizationare set equal to zero (that is our base case). Interpretation of the reported coefficients has to be done with respect to the base case. Our model was estimated with a constant but constant coefficients are not reported here for expositional purposes.

\begin{tabular}{|l|c|c|c|}
\hline \multirow{2}{*}{ Degree Of Globalization } & \multicolumn{3}{|c|}{ Probabilities Conditional on } \\
\cline { 2 - 4 } & TURMOIL IN GERMANY & TURMOIL IN JAPAN & TURMOIL IN USA \\
\hline Low & 40 & 58 & 52 \\
Medium & 36 & 26 & 22 \\
High & 23 & 16 & 26 \\
\hline
\end{tabular}

Notes: Turmoil is defined as observations in the 5th and 95th percentiles.

Probabilities are given in percent terms and are derived from the multinomial logit estimation shown in the top panel. 
Table 10

Strong-Form Globalization

Multinomial Logit Estimation

$$
P(y=i)=\exp \left(x^{\prime} \beta_{i}\right) /\left(1+\sum_{i=1}^{2} \exp \left(x^{\prime} \beta_{i}\right)\right)
$$

\begin{tabular}{|c|c|c|c|c|c|c|c|c|c|}
\hline \multirow[b]{3}{*}{ Degree of Globalization } & \multicolumn{9}{|c|}{ Coefficients } \\
\hline & \multicolumn{3}{|c|}{ TURMOIL IN BRAZIL } & \multicolumn{3}{|c|}{ TURMOIL IN RUSSIA } & \multicolumn{3}{|c|}{ TURMOIL IN THAILAND } \\
\hline & With Financial Center & $\begin{array}{l}\text { Without Financial } \\
\text { Center }\end{array}$ & $\mathrm{p}$-values & With Financial Center & $\begin{array}{l}\text { Without } \\
\text { Financial } \\
\text { Center }\end{array}$ & $\mathrm{p}$-values & With Financial Center & $\begin{array}{l}\text { Without } \\
\text { Financial } \\
\text { Center }\end{array}$ & $\mathrm{p}$-values \\
\hline Medium & $\begin{array}{l}2.14^{\star \star \star} \\
(3.62)\end{array}$ & $\begin{array}{l}1.41^{\star \star \star} \\
(3.61)\end{array}$ & 0.28 & $\begin{array}{l}2.70^{* * *} \\
(4.33)\end{array}$ & $\begin{array}{l}1.36^{\star \star \star} \\
(3.61)\end{array}$ & * & $\begin{array}{l}2.32^{* \star *} \\
(4.03)\end{array}$ & $\begin{array}{l}0.91^{\star *} \\
(2.3)\end{array}$ & ** \\
\hline High & $\begin{array}{l}4.64^{\star \star \star} \\
(8.44)\end{array}$ & $\begin{array}{l}2.47^{\star \star \star} \\
(4.85)\end{array}$ & $\star \star * *$ & $\begin{array}{l}5.53^{\star \star \star} \\
(7.87)\end{array}$ & $\begin{array}{c}1.18 \\
(1.07)\end{array}$ & 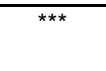 & $\begin{array}{l}2.18^{\star \star \star} \\
(2.6)\end{array}$ & $\begin{array}{c}0.37 \\
(0.63)\end{array}$ & * \\
\hline & Pseudo R2 & 0.13 & & Pseudo R2 & 0.15 & & Pseudo R2 & 0.03 & \\
\hline
\end{tabular}

Notes: Numbers in parentheses represent $z$ statistics. ${ }^{* * *},{ }^{* *},{ }^{*}$ represents the significance of the coefficient at the 1,5

and 10 percent levels. Turmoil is defined as those observations in the 5th and 95th percentiles. The left-hand-side variable captures the degree of globalization. There are three possible degrees of globalization: Low ( when less than 25 percent of the countries in the sample experience turmoil), medium (when more than 25 percent but less than 50 percent of the countries experience turmoil), high ( when 50 percent or more of all countries in the sample experience turmoil). In order to be able to estimate our model, coefficients for the low globalization had to equal zero (that is our base case). Interpretation of the reported coefficients has to be done with respect to the base case. Our model was estimated with a constant but constant coefficients are not reported here for expositional purposes.

$P$ column reports $p$ values for test of equality between parameters estimated with and without Turmoil in Financial Centers.

The financial Center is respectively USA for Brazil, Germany for Russia and Japan for Thailand.

Number of observations for our sample was 694.

\begin{tabular}{|c|c|c|c|c|c|c|c|c|c|}
\hline \multirow{4}{*}{$\begin{array}{c}\text { Degree of } \\
\text { Globalization }\end{array}$} & \multicolumn{9}{|c|}{ Probabilities Conditional on } \\
\hline & \multicolumn{3}{|c|}{ BRAZIL } & \multicolumn{3}{|c|}{ RUSSIA } & \multicolumn{3}{|c|}{ THAILAND } \\
\hline & \multicolumn{2}{|c|}{ TURMOIL } & \multirow[b]{2}{*}{ No Turmoil } & \multicolumn{2}{|l|}{ TURMOIL } & \multirow[b]{2}{*}{ No Turmoil } & \multicolumn{2}{|l|}{ TURMOIL } & \multirow[b]{2}{*}{ No Turmoil } \\
\hline & With Financial Center & $\begin{array}{c}\text { Without Financial } \\
\text { Center }\end{array}$ & & With Financial Center & $\begin{array}{c}\text { Without } \\
\text { Financial } \\
\text { Center }\end{array}$ & & With Financial Center & $\begin{array}{c}\text { Without } \\
\text { Financial } \\
\text { Center }\end{array}$ & \\
\hline Low & 21 & 56 & 87 & 23 & 75 & 92 & 47 & 80 & 90 \\
\hline Medium & 21 & 27 & 10 & 27 & 23 & 7 & 40 & 17 & 8 \\
\hline High & 57 & 17 & 2 & 50 & 2 & 1 & 13 & 4 & 3 \\
\hline
\end{tabular}

Notes: Turmoil is defined as observations in the 5th and 95th percentiles. Probabilities are given in percent terms and are derived from the multinomial logit estimation shown in the top panel. 
Table 11

Strong-Form Globalization

\section{Multinomial Logit Panel Estimation}

$$
P(y=i)=\exp \left(x^{\prime} \beta_{i}\right) /\left(1+\sum_{i=1}^{2} \exp \left(x^{\prime} \beta_{i}\right)\right)
$$

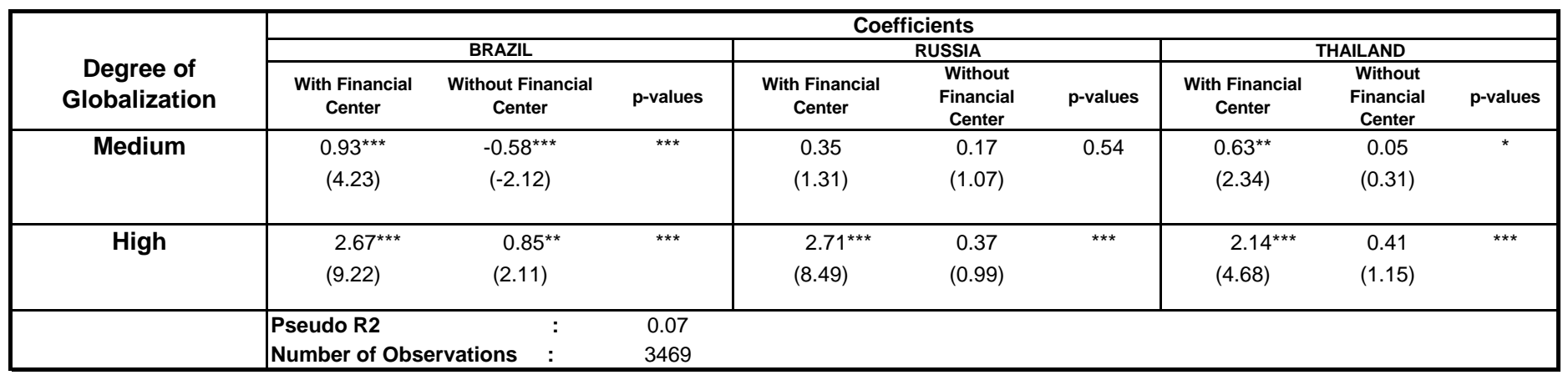

Notes: Numbers in parentheses represent $z$ statistics. ${ }^{* * *},{ }^{* *},{ }^{*}$ represents the significance of the coefficient at the 1,5

and 10 percent levels. Turmoil is defined as those observations in the 5th and 95th percentiles. The left-hand-side variable captures the degree of globalization. There are three possible degrees of globalization: Low ( when less than 25 percent of the countries in the sample experience turmoil), medium (when more than 25 percent but less than 50 percent of the countries experience turmoil), high (when 50 percent or more of all countries in the sample experience turmoil). In order to be able to estimate our model, coefficients for the low globalization had to equal zero (that is our base case). Interpretation of the reported coefficients has to be done with respect to the base case. Our model was estimated with a constant but constant coefficients are not reported here for expositional purposes.

$\mathrm{P}$ column reports $\mathrm{p}$ values for test of equality between parameters estimated with and without Turmoil in Financial Centers. The financial Center is respectively USA for Brazil, Germany for Russia and Japan for Thailand.

\begin{tabular}{|c|c|c|c|c|c|c|c|}
\hline \multirow{2}{*}{$\begin{array}{c}\text { Degree Of } \\
\text { Globalization }\end{array}$} & \multirow{2}{*}{ No Turmoil } & \multicolumn{2}{|c|}{ Turmoil in Brazil } & \multicolumn{2}{|c|}{ Turmoil in Russia } & \multicolumn{2}{c|}{ Turmoil in Thailand } \\
\cline { 2 - 8 } & & $\begin{array}{c}\text { With Financial } \\
\text { Center }\end{array}$ & $\begin{array}{c}\text { Without } \\
\text { financial } \\
\text { Center }\end{array}$ & $\begin{array}{c}\text { With Financial } \\
\text { Center }\end{array}$ & $\begin{array}{c}\text { Without } \\
\text { Financial } \\
\text { Center }\end{array}$ & $\begin{array}{c}\text { With } \\
\text { Financial } \\
\text { Center }\end{array}$ & $\begin{array}{c}\text { Without financial } \\
\text { Center }\end{array}$ \\
\hline Low & 77 & 51 & 84 & 61 & 70 & 60 & 76 \\
Medium & 21 & 36 & 13 & 24 & 28 & 31 & 22 \\
High & 1 & 13 & 3 & 15 & 2 & 9 & 2 \\
\hline
\end{tabular}

Notes: Turmoil is defined as observations in the 5th and 95th percentiles. Probabilities are given in Percent terms and are derived from the multinomial logit estimation shown in the top panel. 
Table 12

Strong-Form Globalization

Multinomial Logit Panel Estimation

$$
P(y=i)=\exp \left(x^{\prime} \beta_{i}\right) /\left(1+\sum_{i=1}^{2} \exp \left(x^{\prime} \beta_{i}\right)\right)
$$

\begin{tabular}{|c|c|c|c|}
\hline \multirow[b]{2}{*}{$\begin{array}{l}\text { Degree of } \\
\text { Globalization }\end{array}$} & \multicolumn{3}{|c|}{$\begin{array}{c}\text { Coefficients } \\
\text { Emerging Markets }\end{array}$} \\
\hline & $\begin{array}{l}\text { With Financial } \\
\text { Center }\end{array}$ & $\begin{array}{c}\text { Without } \\
\text { Financial } \\
\text { Center }\end{array}$ & $p$-value \\
\hline Medium & $\begin{array}{l}0.65^{\star \star \star} \\
(4.76)\end{array}$ & $\begin{array}{c}0.01 \\
(0.11)\end{array}$ & *** \\
\hline \multirow[t]{2}{*}{ High } & $\begin{array}{l}2.64^{\star \star \star} \\
(14.64)\end{array}$ & $\begin{array}{l}0.57^{\star \star \star} \\
(2.71)\end{array}$ & *** \\
\hline & $\begin{array}{c}\text { Pseudo R2 } \\
\text { \#Observations }\end{array}$ & $\begin{array}{r}0.07 \\
3469\end{array}$ & \\
\hline
\end{tabular}

Notes: Numbers in parentheses represent $z$ statistics. ${ }^{* * *},{ }^{* *},{ }^{*}$ represents the significance of the coefficient at the 1,5

and 10 percent levels. Turmoil is defined as those observations in the 5 th and 95 th percentiles. The left-hand-side variable captures the degree of globalization. There are three possible degrees of globalization: Low ( when less than 25 percent of the countries in the sample experience turmoil), medium (when more than 25 percent but less than 50 percent of the countries experience turmoil), high (when 50 percent or more of all countries in the sample experience turmoil). In order to be able to estimate our model, coefficients for the low globalization had to equal zero (that is our base case). Interpretation of the reported coefficients has to be done with respect to the base case. Our model was estimated with a constant but constant coefficients are not reported here for expositional purposes. $P$ column reports $p$ values for test of equality between parameters estimated With and Without Turmoil in Financial Centers. The explanatory variable is emerging market. Such variable could equal $0,1,2,3$ depending on how many emerging markets (Brazil,Russia,Thailand) experienced turmoil concurrently.

\begin{tabular}{|c|c|c|c|c|c|c|c|}
\hline & \multicolumn{4}{|c|}{ Probabilities Conditional on } \\
\cline { 2 - 7 } $\begin{array}{c}\text { Degree of } \\
\text { Globalization }\end{array}$ & \multirow{3}{*}{ No Turmoil } & \multicolumn{2}{|c|}{$\begin{array}{c}\text { TURMOIL IN ONE EMERGING } \\
\text { MARKET }\end{array}$} & \multicolumn{2}{|c|}{$\begin{array}{c}\text { TURMOIL IN TWO EMERGING } \\
\text { MARKETS }\end{array}$} & \multicolumn{3}{c|}{$\begin{array}{c}\text { TURMOIL IN THREE } \\
\text { EMERGING MARKETS }\end{array}$} \\
\cline { 3 - 8 } & & $\begin{array}{c}\text { With Financial } \\
\text { Center }\end{array}$ & $\begin{array}{c}\text { Without } \\
\text { Financial Center }\end{array}$ & $\begin{array}{c}\text { With Financial } \\
\text { Center }\end{array}$ & $\begin{array}{c}\text { Without } \\
\text { Financial } \\
\text { Center }\end{array}$ & $\begin{array}{c}\text { With Financial } \\
\text { Center }\end{array}$ & $\begin{array}{c}\text { Without } \\
\text { Financial } \\
\text { Center }\end{array}$ \\
\hline Low & 77 & 56 & 76 & 19 & 75 & 2 & 73 \\
Medium & 21 & 31 & 22 & 20 & 22 & 4 & 21 \\
High & 1 & 13 & 2 & 62 & 4 & 94 & 6 \\
\hline
\end{tabular}

Notes:

Turmoil is defined as observations in the 5th and 95th percentiles. Probabilities are given in percent terms and are derived from the multinomial logit estimation shown in the top panel. 
TABLE 13

Days of Globalization: Asymmetries, Origins and Size of Shocks

Asymmetries

\begin{tabular}{|c|c|c|}
\hline \multirow{2}{*}{ Regions } & \multicolumn{2}{|c|}{ Days of High Globalization } \\
\hline & $\begin{array}{c}\text { Proportion of } \\
\text { Crashes }\end{array}$ & $\begin{array}{c}\text { Proportion of } \\
\text { Rallies }\end{array}$ \\
\hline World & 85 & 15 \\
\hline Asia & 29 & 71 \\
\hline Latin America & 69 & 31 \\
\hline Europe & 61 & 39 \\
\hline G7 & 56 & 44 \\
\hline Transition Economies & 61 & 39 \\
\hline
\end{tabular}

Note: Numbers reported in the above table are in percent.

News on Days of High globalization

\begin{tabular}{|c|c|c|c|c|c|c|c|c|c|c|}
\hline \multirow{4}{*}{ Regions } & \multicolumn{10}{|c|}{ Proportion of Days with News about the } \\
\hline & \multicolumn{4}{|c|}{ Financial Sector } & \multirow{2}{*}{\multicolumn{2}{|c|}{ Economy and Politics }} & \multicolumn{2}{|c|}{ Monetary Policy } & \multicolumn{2}{|c|}{ International Agreements } \\
\hline & \multicolumn{2}{|c|}{ BANKING } & \multicolumn{2}{|c|}{ OTHER } & & & & & & \\
\hline & Center & Periphery & Center & Periphery & Center & Periphery & Center & Periphery & Center & Periphery \\
\hline Regional & 8 & 8 & 18 & 23 & 11 & 10 & 11 & 3 & 2 & 7 \\
\hline World & 10 & 10 & 30 & 15 & 10 & 10 & 10 & 5 & & \\
\hline
\end{tabular}

Note : Numbers in the above table are in percent.

\section{Degree of Globalization and Size of Returns}

\begin{tabular}{|l|ccc|}
\hline \multicolumn{1}{|c|}{ Degree of World Globalization } & \multicolumn{3}{|c|}{ Returns } \\
\cline { 2 - 4 } & Small & Medium & Large \\
\hline \multirow{2}{*}{ LOW } & 46 & 48 & 5 \\
MEDIUM & 12 & 86 & 2 \\
HIGH & 0 & 92 & 8 \\
\hline
\end{tabular}

Notes: Numbers in the above table are in percent.

Small returns are returns between the 3rd (97th) and 5th (95th) percentiles.

Medium Returns are returns between the 1st (99th) and 3rd (97th) percentiles.

Large Returns are returns in the 1st (99th) percentile.

The first cell of this table indicates that 46 percent of the days of low globalization had countries experiencing on average

a small return. 


\section{Appendix Table \\ The Globalization of Financial Turmoil: Chronology of News January 1, 1997 to August 31,1999}

\begin{tabular}{|c|c|c|c|c|c|c|c|}
\hline DAY & ALL & ASIA & EUR & G7 & LA & TRA & NEWS \\
\hline 7-Apr-97 & & & 57 & & & & $\begin{array}{l}\text { EUR: European and US Stocks up, benefiting from } \\
\text { comments of EU finance ministers who indicated the } \\
\text { single currency will begin on time. (FS-OTHER, } \\
\text { CENTER) }\end{array}$ \\
\hline 28-Aug-97 & & 71 & & & & & $\begin{array}{l}\text { ASIA: Investors flee the region amid a deepening loss } \\
\text { of confidence in the ability of governments to tackle } \\
\text { their severe economic problems. (E\&PN, } \\
\text { PERIPHERY) }\end{array}$ \\
\hline 22-Oct-97 & & 57 & & & & & $\begin{array}{l}\text { ASIA: Share prices fall sharply in Asian markets due } \\
\text { to a sharp drop in futures prices in Singapore and } \\
\text { fears about higher interest rates and currency stability } \\
\text { in Hong Kong. (FS-OTHER,PERIPHERY) }\end{array}$ \\
\hline 23-Oct-97 & & & 57 & 71 & 57 & & $\begin{array}{l}\text { G7, EUR, LA: Hong Kong Monetary Authority was } \\
\text { forced to sell US dollars to support the currency, } \\
\text { triggering interest rate hikes that prompted a global } \\
\text { sell off. (FS-OTHER, PERIPHERY) }\end{array}$ \\
\hline 27-Oct-97 & 57 & & 71 & 86 & 86 & & $\begin{array}{l}\text { EUR, G7, LA: A } \$ 600 \text { billion sell-off shut down the US } \\
\text { market for the first time since } 1981 \text {. The sell-off was } \\
\text { triggered by Southeast Asia's shaky economies, by a } \\
\text { jump in interest rates, as well as by a stream of weak } \\
\text { earning reports. Panic grips other regions as US } \\
\text { market crashes especially after the Hong Kong } \\
\text { declines of the past week. (E\&PN, PERIPHERY); } \\
\text { (FS-OTHER, CENTER) }\end{array}$ \\
\hline 28-Oct-97 & 80 & 100 & 86 & 86 & 71 & 57 & $\begin{array}{l}\text { ASIA, EUR, TRA, G7: still reacting to US-market- } \\
\text { crash and Hong Kong crash. (FS-OTHER, CENTER) } \\
\text { LA: Markets soar as US market rallies. (FS- } \\
\text { OTHER, CENTER) }\end{array}$ \\
\hline 29-Oct-97 & 63 & 57 & 71 & 86 & & 71 & $\begin{array}{l}\text { EUR, G7, TRA: Markets soared as US soared the } \\
\text { day before. (FS-OTHER, CENTER) } \\
\text { ASIA: Asian markets finish lower as investors fear } \\
\text { another steep drop in US markets. (FS-OTHER, } \\
\text { CENTER) }\end{array}$ \\
\hline 30-Oct-97 & & & 71 & & 57 & & $\begin{array}{l}\text { EUR: Stocks soared after Greenspan eased concern } \\
\text { that inflation could be on the rise. (MP, CENTER) } \\
\text { LA: Strong declines in the region stemmed from } \\
\text { contagion in Asia. Fears about Brazil 's real currency } \\
\text { and liquidity crunch of its banking system. (FS- } \\
\text { OTHER, PERIPHERY); } \\
\text { PERIPHERY) }\end{array}$ \\
\hline 3-Nov-97 & & 57 & & & & & $\begin{array}{l}\text { ASIA: Stocks rally as a financial aid package to } \\
\text { Indonesia restores calm to the region. China also } \\
\text { eases credit. (IA, PERIPHERY); (MP, PERIPHERY) }\end{array}$ \\
\hline 7-Nov-97 & & & & 57 & & & $\begin{array}{l}\text { G7: The US dollar surges reaching a six-month high } \\
\text { as concerns increased in the market over the ability }\end{array}$ \\
\hline
\end{tabular}




\begin{tabular}{|c|c|c|c|c|c|c|c|}
\hline DAY & $\overline{A L L}$ & ASIA & EUR & G7 & LA & TRA & \begin{tabular}{|c|} 
NEWS \\
\end{tabular} \\
\hline & & & & & & & $\begin{array}{l}\text { of the Japanese government to revive the country's } \\
\text { economy. (E\&PN, CENTER) }\end{array}$ \\
\hline 12-Nov-97 & & & & & 71 & 71 & $\begin{array}{l}\text { LA: Concern about fiscal austerity package } \\
\text { announced by Brazil. Markets also fall after steep } \\
\text { declines in Asian markets. (E\&PN, PERIPHERY), } \\
\text { (FS-OTHER, PERIPHERY) } \\
\text { TRA: Stocks fall after major drops in Asian markets. } \\
\text { (FS-OTHER, PERIPHERY) }\end{array}$ \\
\hline 17-Nov-97 & & & 86 & 57 & & & $\begin{array}{l}\text { EUR, G7: Stocks up as Japan PM hints that public } \\
\text { spending may be used to stimulate the economy and } \\
\text { protect depositors following the collapse of the } \\
\text { nation's largest bank. US reports low inflation } \\
\text { measures. (FS-BANKING CENTER); (E\&PN, } \\
\text { CENTER) }\end{array}$ \\
\hline 24-Nov-97 & & & 57 & & & & $\begin{array}{l}\text { EUR: Shares fall after the collapse of Japan's fourth } \\
\text { largest brokerage firm, Yamaichi Securities company. } \\
\text { (FS-BANKING, CENTER) }\end{array}$ \\
\hline 1-Dec-97 & & & & 57 & & & $\begin{array}{l}\text { G7: Stock markets rally on gains in Asian markets } \\
\text { overnight (FS-OTHER, PERIPHERY) }\end{array}$ \\
\hline 11-Dec-97 & & 100 & 57 & & & & $\begin{array}{l}\text { ASIA: Stocks slumped as Moody's cut rating of South } \\
\text { Korea's currency. (E\&PN, PERIPHERY) } \\
\text { EUR: Stocks down amid a new wave of selling in } \\
\text { Asian markets and signs of weakness in the US } \\
\text { economy (FS-OTHER, PERIPHERY); (E\&PN, } \\
\text { CENTER) }\end{array}$ \\
\hline 9-Jan-98 & & & & & 71 & & $\begin{array}{l}\text { LA: Asian turmoil, especially concerns about } \\
\text { Indonesia, causes markets declines. Central Bank of } \\
\text { Chile raises key interest rate (FS-OTHER, } \\
\text { PERIPHERY); (MP, PERIPHERY) }\end{array}$ \\
\hline 12-Jan-98 & & & 71 & & & 71 & $\begin{array}{l}\text { EUR, TRA: Peregrine, one of Asia's largest } \\
\text { investment banks (Hong Kong), files for liquidation } \\
\text { raising concerns about emerging markets in general } \\
\text { (FS-BANKING, PERIPHERY) }\end{array}$ \\
\hline 13-Jan-98 & & 71 & & & & & $\begin{array}{l}\text { ASIA: Stocks rose on optimism about IMF backed } \\
\text { reforms for the region (IA, PERIPHERY) }\end{array}$ \\
\hline 14-Jan-98 & & 86 & & & & & $\begin{array}{l}\text { ASIA: Stocks continued to rise on optimism about } \\
\text { IMF backed reforms for the region (IA, PERIPHERY) }\end{array}$ \\
\hline 19-Jan-98 & & 100 & & & & & $\begin{array}{l}\text { ASIA: Indonesia signaled commitment to the much } \\
\text { awaited bank reform. Camdessus issues statement } \\
\text { of confidence about Malaysia and countries in the } \\
\text { region.(FS-BANKING, PERIPHERY); } \\
\text { PERIPHERY) }\end{array}$ \\
\hline 22-Jan-98 & & 57 & & & & & $\begin{array}{l}\text { ASIA: The plunging Indonesian rupiah dragged the } \\
\text { rest of Asia into a downward spiral. (FS-OTHER, } \\
\text { PERIPHERY) }\end{array}$ \\
\hline 2-Feb-98 & & 71 & & & & & $\begin{array}{l}\text { ASIA: Stocks up as value oriented funds flooded back } \\
\text { into Asia from Europe and US. Strength driven by } \\
\text { liquidity even though nothing changed in the } \\
\text { fundamentals front. (FS-OTHER, PERIPHERY) }\end{array}$ \\
\hline 27-Apr-98 & & & 86 & 86 & & & $\begin{array}{l}\text { EUR, G7: Concern US will raise interest rates to fight } \\
\text { Inflation (MP, CENTER) }\end{array}$ \\
\hline 26-May-98 & & & & & 57 & & LA: Concerns about a potential devaluation in Russia \\
\hline
\end{tabular}




\begin{tabular}{|c|c|c|c|c|c|c|c|}
\hline DAY & ALL & ASIA & EUR & G7 & LA & TRA & NEWS \\
\hline & & & & & & & $\begin{array}{l}\text { affecting Brazil and other emerging markets. (FS- } \\
\text { OTHER, PERIPHERY) }\end{array}$ \\
\hline 27-May-98 & & & 57 & & & & $\begin{array}{l}\text { EUR: Speculation about Russian devaluation of the } \\
\text { ruble caused fall in stock prices. (FS-OTHER, } \\
\text { PERIPHERY) }\end{array}$ \\
\hline 1-Jun-98 & & & & & & 57 & $\begin{array}{l}\text { TRA: Russian stock prices plummeted while the main } \\
\text { market for Russian futures announced that it was } \\
\text { suspending trading indefinitely. Unfulfilled } \\
\text { expectations of foreign aid to Russia contributed to } \\
\text { the declines. (FS-OTHER, PERIPHERY); (IA, } \\
\text { PERIPHERY) }\end{array}$ \\
\hline 15-Jun-98 & 51 & 86 & 57 & & 57 & & $\begin{array}{l}\text { ASIA: Japanese government announced that GDP } \\
\text { contracted for a second consecutive quarter. (E\&PN, } \\
\text { CENTER) } \\
\text { ASIA, LA, G7, TRA: Loss of confidence in emerging } \\
\text { markets in general as Russian market tumbled for a } \\
\text { seventh straight day. (FS-OTHER, PERIPHERY) }\end{array}$ \\
\hline 17-Jun-98 & & 71 & & & & & $\begin{array}{l}\text { ASIA: US and Japan coordinated actions to sell US } \\
\text { dollars and buy Japanese yens. Markets soared due } \\
\text { to the stronger yen. (IA, CENTER) }\end{array}$ \\
\hline 18-Jun-98 & & 100 & & & & & $\begin{array}{l}\text { ASIA: Countries in the region still reacting to the US } \\
\text { and Japan coordinated actions to prop up the yen (IA, } \\
\text { CENTER) }\end{array}$ \\
\hline 14-Jul-98 & & & & & & 71 & $\begin{array}{l}\text { TRA: Russia would receive } 22.6 \text { billion dollars from } \\
\text { IMF and other bilateral donors (IA, PERIPHERY) }\end{array}$ \\
\hline 11-Aug-98 & 60 & & 86 & 71 & 57 & & $\begin{array}{l}\text { EUR, G7, LA: Foreign investors seemed to be the } \\
\text { main driving force behind the market drop. Fears of a } \\
\text { weaker yen, and the prospect of devaluation in China } \\
\text { sent shock waves throughout the world. (FS-OTHER, } \\
\text { CENTER); (FS-OTHER, PERIPHERY) }\end{array}$ \\
\hline 13-Aug-98 & & & & & & 71 & $\begin{array}{l}\text { TRA: Russian shares fell more than } 10 \text { percent early } \\
\text { on growing fears of a liquidity crisis among } \\
\text { Russian banks. (FS-BANKING, PERIPHERY) }\end{array}$ \\
\hline 18-Aug-98 & & & 57 & & & & $\begin{array}{l}\text { EUR: Gains in European markets following a major } \\
\text { Wall Street advance (FS-OTHER, CENTER) }\end{array}$ \\
\hline 20-Aug-98 & & & & & 71 & & $\begin{array}{l}\text { LA: Concern Russian banks may fail and Venezuela } \\
\text { may devalue (FS-BANKING, PERIPHERY); (FS- } \\
\text { OTHER, PERIPHERY) }\end{array}$ \\
\hline 21-Aug-98 & 54 & & 71 & 71 & 71 & & $\begin{array}{l}\text { LA: Concern about imminent currency devaluation in } \\
\text { Venezuela. (FS-OTHER, PERIPHERY) } \\
\text { EUR, G7, LA: Russia's Central Bank stated that } \\
\text { some Russian banks could go bankrupt accentuating } \\
\text { the Russian financial crisis. In Germany (a major } \\
\text { lender to Russia) stocks plunged, triggering downfalls } \\
\text { in London and Paris (FS-BANKING, PERIPHERY); } \\
\text { (FS-OTHER, CENTER) }\end{array}$ \\
\hline 26-Aug-98 & & & 71 & & & & $\begin{array}{l}\text { EUR: Stocks fall as Russia announces its debt } \\
\text { restructuring plan (FS-OTHER, PERIPHERY) }\end{array}$ \\
\hline 27-Aug-98 & 74 & & 86 & 100 & 100 & 86 & $\begin{array}{l}\text { EUR, G7, LA, TRA: Russia's government unable to } \\
\text { sell its newly restructured GKO bills spreading fear } \\
\text { that global crisis will continue. (FS-OTHER, } \\
\text { PERIPHERY) }\end{array}$ \\
\hline
\end{tabular}




\begin{tabular}{|c|c|c|c|c|c|c|c|}
\hline DAY & ALL & ASIA & EUR & G7 & LA & TRA & NEWS \\
\hline 1-Sep-98 & & & 57 & & 57 & & $\begin{array}{l}\text { LA: Stocks end sharply higher mirroring the DJIA's } \\
\text { rebound (FS-OTHER, CENTER) } \\
\text { EUR: Stocks up on optimism about Europe's } \\
\text { prospects. (FS-OTHER, CENTER) }\end{array}$ \\
\hline 2-Sep-98 & & & 71 & & & 57 & $\begin{array}{l}\text { TRA: Markets rebound as investors went for } \\
\text { bargains. (FS-OTHER, PERIPHERY) } \\
\text { EUR: Stocks follow rebound in the US stock market. } \\
\text { (FS-OTHER, CENTER) }\end{array}$ \\
\hline 3-Sep-98 & & & 57 & 57 & 57 & & $\begin{array}{l}\text { LA: Moody's downgraded Brazil's and Venezuela's } \\
\text { foreign debt and put Argentina's foreign currency } \\
\text { debt and } 11 \text { banks on review for a possible } \\
\text { downgrade. (E\&PN, PERIPHERY), (FS-BANKING, } \\
\text { PERIPHERY) } \\
\text { EUR, G7: European stock markets were hurt by a } \\
\text { dollar plunge and worries that financial troubles are } \\
\text { spreading from Russia and Asia to Latin America. } \\
\text { (FS-OTHER, PERIPHERY) }\end{array}$ \\
\hline 4-Sep-98 & & & & & & 57 & $\begin{array}{l}\text { TRA: Russia's parliament delays a vote on } \\
\text { Chernomyrdin's appointment as Prime Minister at } \\
\text { Yeltsin's request. (E\&PN, PERIPHERY) } \\
\end{array}$ \\
\hline 7-Sep-98 & & 57 & 57 & & & & $\begin{array}{l}\text { ASIA: Stronger yen and a higher stock market helps } \\
\text { Japanese banks but fund managers stay skeptical } \\
\text { (FS-BANKING, CENTER). } \\
\text { EUR: Greenspan hints he would favor cutting interes } \\
\text { rates. (MP, CENTER) }\end{array}$ \\
\hline 8-Sep-98 & & & & 57 & & 57 & $\begin{array}{l}\text { G7, TRA: Renewed confidence was felt thanks to } \\
\text { market supportive comments from Fed Chairman } \\
\text { Alan Greenspan.(MP, CENTER) }\end{array}$ \\
\hline 10-Sep-98 & 60 & & 71 & 71 & 86 & 57 & $\begin{array}{l}\text { EUR, G, TRA, LA: Worries about banks exposures as } \\
\text { S\&P downgrades Spain's second largest bank. } \\
\text { Credit ratings for Argentina's two largest banks were } \\
\text { also reduced. (FS-BANKING, CENTER); } \\
\text { BANKING, PERIPHERY) } \\
\end{array}$ \\
\hline 11-Sep-98 & & & & & & 57 & $\begin{array}{l}\text { LA: Brazilian Government boosted overnight interest } \\
\text { rates by } 20 \text { percentage points to try to stem capital } \\
\text { flight, which reached } 2.2 \text { billion dollars the day before. } \\
\text { (FS-OTHER, PERIPHERY) }\end{array}$ \\
\hline 14-Sep-98 & & & & 71 & & 71 & $\begin{array}{l}\text { G7, TRA: Russia's new PM pledges to revive the } \\
\text { economy. (E\&PN, PERIPHERY) }\end{array}$ \\
\hline 15-Sep-98 & & & & & 86 & 57 & $\begin{array}{l}\text { LA, TRA: G7 meeting hints at financial aid for Latin } \\
\text { America. Argentina may borrow } 5.7 \text { billion dollars } \\
\text { from the World Bank and other international } \\
\text { institutions. (IA, PERIPHERY) }\end{array}$ \\
\hline 17-Sep-98 & 54 & & 86 & 86 & & & $\begin{array}{l}\text { EUR, G7: Greenspan states that there is no move to } \\
\text { coordinate interest rates (MP, CENTER) }\end{array}$ \\
\hline 21-Sep-98 & & & 86 & 57 & & & $\begin{array}{l}\text { G7, EUR: Concern about Japan's recession and low } \\
\text { growth potential for OECD countries due to emerging } \\
\text { markets collapse and deepening financial collapse. } \\
\text { Political parties in Japan remains at odds on how to } \\
\text { use taxpayer money to prop up LTCB of Japan. }\end{array}$ \\
\hline
\end{tabular}




\begin{tabular}{|c|c|c|c|c|c|c|c|}
\hline DAY & ALL & ASIA & EUR & G7 & LA & TRA & NEWS \\
\hline & & & & & & & $\begin{array}{l}\text { (E\&PN, CENTER); (FS-OTHER, EMERGING); (FS- } \\
\text { BANKING, CENTER) }\end{array}$ \\
\hline 22-Sep-98 & & & 71 & & & & $\begin{array}{l}\text { EUR: US markets rebound day after the Clinton } \\
\text { grand jury testimony. (E\&PN, CENTER) }\end{array}$ \\
\hline 23-Sep-98 & & & 57.14 & 57 & 100 & & $\begin{array}{l}\text { LA: President of IDB says Brazil could receive up to } \\
50 \text { billion dollars in aid from international institutions. } \\
\text { IMF and US also gave statements of support for } \\
\text { Brazil Aid. (IA, PERIPHERY) } \\
\text { G7, EUR: Investors hope that Greenspan will hint at a } \\
\text { possible rate cut when he testifies before the senate } \\
\text { banking committee. (MP, CENTER) }\end{array}$ \\
\hline 24-Sep-98 & & 86 & & & 57 & & $\begin{array}{l}\text { ASIA: Stocks up as Greenspan suggests he may } \\
\text { lower interest rates. (MP, CENTER) } \\
\text { LA: Stocks down as concern over banks is felt after } \\
\text { some of the largest banks put together a } 4 \text { billion } \\
\text { dollar bailout of LTCM raising concern about credit. } \\
\text { Brazil announces fiscal austerity measures. (E\&PN, } \\
\text { PERIPHERY); (FS-BANKING,CENTER) }\end{array}$ \\
\hline 25-Sep-98 & & & & & & 71 & $\begin{array}{l}\text { TRA: Russian tax collection continued to plummet in } \\
\text { September, due to the crash on Russian financial } \\
\text { markets and the country's ensuing banking crisis } \\
\text { (statement by tax official). (E\&PN, PERIPHERY) }\end{array}$ \\
\hline 30-Sep-98 & & & & 57 & & & $\begin{array}{l}\text { G7: US cut interest rates and asked other countries } \\
\text { to follow suit. (MP, CENTER) }\end{array}$ \\
\hline 1-Oct-98 & 66 & & 86 & 100 & 71 & & $\begin{array}{l}\text { G7, EUR, LA: Concerns about global economic } \\
\text { slump. Report US manufacturing production } \\
\text { weakened for fourth straight month as exports } \\
\text { slumped. (E\&PN, CENTER) }\end{array}$ \\
\hline 2-Oct-98 & & & & & 57 & 57 & $\begin{array}{l}\text { LA: Stock markets soared on hopes of a financial } \\
\text { package for troubled Brazil (IA, PERIPHERY) } \\
\text { TRA: Stocks still falling following global declines of } \\
\text { October first. (FS-OTHER, CENTER) }\end{array}$ \\
\hline 6-Oct-98 & & & & 57 & & & $\begin{array}{l}\text { G7: Disappointment that the G7 meeting in } \\
\text { Washington failed to adopt a clear strategy to } \\
\text { address global economic issues drove share prices } \\
\text { sharply lower in world markets. (IA, CENTER) }\end{array}$ \\
\hline 8-Oct-98 & 51 & & 86 & 71 & & & $\begin{array}{l}\text { EUR, G7: Speculation the Fed would cut interest } \\
\text { rates. Japan moves to repair its economy. (MP, } \\
\text { CENTER) (E\&PN, CENTER) }\end{array}$ \\
\hline & & & & & & & $\begin{array}{l}\text { ASIA, G7: Interest cuts in UK and other European } \\
\text { countries in the preceding week generated rallies in } \\
\text { several markets. (MP, CENTER) }\end{array}$ \\
\hline 9-Oct-98 & & 57 & & 57 & 57 & & $\begin{array}{l}\text { LA: Brazilian authorities and the International } \\
\text { Monetary Fund issued a joint statement on the } \\
\text { availability of a rescue package to help cushion the } \\
\text { region from market turmoil (IA, PERIPHERY) }\end{array}$ \\
\hline 12-Oct-98 & 54 & 57 & 71 & 71 & & & $\begin{array}{l}\text { EUR, G7, ASIA: Japan will substantially increase the } \\
\text { amount of money it will spend on shoring up its fragile } \\
\text { banking system. (FS-BANKING, CENTER) }\end{array}$ \\
\hline $16-$ Oct-98 & & 71 & 71 & & & & EUR, G7: Fed Funds rate cut by a quarter \\
\hline
\end{tabular}




\begin{tabular}{|c|c|c|c|c|c|c|c|}
\hline DAY & ALL & ASIA & EUR & G7 & LA & TRA & NEWS \\
\hline & & & & & & & percentage point on Oct. $15^{\text {th }}$. (MP,CENTER) \\
\hline 20-Oct-98 & & & 57 & 57 & & & $\begin{array}{l}\text { EUR, G7: Suggestions that France and Germany } \\
\text { would lower their interest rates boosted investor } \\
\text { sentiment in Europe as well as continued gains in the } \\
\text { USA and a rally in Asian markets (MP, CENTER); } \\
\text { (FS-OTHER, CENTER); (FS-OTHER, PERIPHERY) }\end{array}$ \\
\hline 27-Oct-98 & & & 71 & & & & $\begin{array}{l}\text { EUR: Italy makes a surprise cut in interest rate by a } \\
\text { full percentage point. (MP, CENTER) }\end{array}$ \\
\hline 30-Oct-98 & & & & & 71 & & $\begin{array}{l}\text { LA: G7 countries said they would back a new IMF } \\
\text { credit line to Brazil, speeding aid to Brazil. } \\
\text { (IA,PERIPHERY) }\end{array}$ \\
\hline 2-Nov-98 & & & 71 & & & 57 & $\begin{array}{l}\text { EUR, TRA: Stocks rallied after the October } 30^{\text {th }} \text { US } \\
\text { commerce department report announcing better than } \\
\text { expected third quarter growth rates. (E\&PN, } \\
\text { CENTER) }\end{array}$ \\
\hline 4-Nov-98 & & & & 71 & & & $\begin{array}{l}\text { G7: Democrats increased seats in the US } \\
\text { Congressional elections, the first party with an } \\
\text { incumbent resident to do this since 1934. Stocks rally } \\
\text { after interest rate cuts in Italy and Sweden in the pas } \\
\text { week (E\&PN, CENTER); (MP, CENTER) }\end{array}$ \\
\hline 10-Nov-98 & & 57 & & & & & $\begin{array}{l}\text { ASIA: Investors await the release of the Japanese } \\
\text { government's stimulus package (E\&PN, CENTER). }\end{array}$ \\
\hline 11-Nov-98 & & 57 & & & & & $\begin{array}{l}\text { ASIA: Japan's newest economic stimulus package is } \\
\text { expected to be the largest ever. (E\&PN, CENTER) }\end{array}$ \\
\hline 20-Nov-98 & & & & 57 & & & $\begin{array}{l}\text { EUR: European stocks finished with strong gains as } \\
\text { bourses benefited from hopes of further European } \\
\text { rate cuts. (MP, CENTER) }\end{array}$ \\
\hline 30-Nov-98 & & & & 57 & 57 & & $\begin{array}{l}\text { G7: Global markets were given a boost after the DJIA } \\
\text { marked a record high. (FS-OTHER, CENTER) } \\
\text { LA: Latin American investors were influenced by } \\
\text { heavy profit taking on Wall Street and Brazil. (FS- } \\
\text { OTHER, PERIPHERY) }\end{array}$ \\
\hline 1-Dec-98 & & & 57 & 71 & & & $\begin{array}{l}\text { G7, EUR: Stocks down on weak dollar (FS, CENTER, } \\
\text { OTHER) }\end{array}$ \\
\hline 3-Dec-98 & & & & & 57 & & $\begin{array}{l}\text { LA: The US dollar weakened as investors were } \\
\text { discouraged by the continuing decline in U.S. stocks } \\
\text { and Wednesday's defeat in the Brazilian Congress of } \\
\text { an important government austerity measure. (FS- } \\
\text { OTHER, CENTER); (E\&PN, PERIPHERY) }\end{array}$ \\
\hline 21-Dec-98 & & & & 57 & & & $\begin{array}{l}\text { G7: High expectations on the Euro boost stocks. } \\
\text { (FS-OTHER, CENTER) }\end{array}$ \\
\hline 4-Jan-99 & & & 86 & 57 & & & $\begin{array}{l}\text { EUR, G7: Stock prices ended up higher lured by a } \\
\text { weak dollar and start of Euro trading. (FS-OTHER, } \\
\text { CENTER) }\end{array}$ \\
\hline & & & & & & & $\begin{array}{l}\text { G7: US rallied on the back of technology stocks. (FS- } \\
\text { OTHER, CENTER) }\end{array}$ \\
\hline 6-Jan-99 & & 57 & & 71 & & & $\begin{array}{l}\text { ASIA: Japanese market followed an overnight jump } \\
\text { in New York stocks lead by strength in the high- } \\
\text { technology sector. (FS-OTHER, CENTER) }\end{array}$ \\
\hline 12-Jan-99 & & & & & 57 & & $\begin{array}{l}\text { LA: Markets closed sharply lower due to rumors of } \\
\text { an interest rate hike in Brazil and a near } \$ 200 \text { million } \\
\text { outflow. (FS-OTHER, PERIPHERY) }\end{array}$ \\
\hline
\end{tabular}




\begin{tabular}{|c|c|c|c|c|c|c|c|}
\hline DAY & ALL & ASIA & EUR & G7 & LA & TRA & NEWS \\
\hline 13-Jan-99 & 66 & & 100 & 57 & 86 & 57 & $\begin{array}{l}\text { EUR, LA, TRA: Brazil's Central Bank Chairman } \\
\text { resigns. } \quad \text { Brazil devalues its currency. (E\&PN, } \\
\text { PERIPHERY); (MP, PERIPHERY) }\end{array}$ \\
\hline 14-Jan-99 & & & & & 57 & & $\begin{array}{l}\text { LA: Standard \& Poor's downgraded certain Latin } \\
\text { American Banks and some of Brazil's foreign } \\
\text { currency debt. (FS-BANKING, PERIPHERY) }\end{array}$ \\
\hline 15-Jan-99 & & & & & 71 & & $\begin{array}{l}\text { LA: Brazil lets its currency float against the dollar (FS- } \\
\text { OTHER, PERIPHERY) }\end{array}$ \\
\hline 18-Jan-99 & & & 57 & & & & $\begin{array}{l}\text { EUR: Bank mergers in France, Spain and calmer } \\
\text { financial markets in Brazil pushed stocks higher (FS- } \\
\text { BANKING, CENTER); (FS-OTHER, PERIPHERY). }\end{array}$ \\
\hline 9-Feb-99 & & & & 57 & & & $\begin{array}{l}\text { G7: There were growing concerns in Europe about a } \\
\text { slowdown in the economy. European markets fell } \\
\text { following financial turmoil in emerging markets. } \\
\text { Japanese investors were waiting for measures, if any, } \\
\text { from the BOJ to curb the recent sharp rise in bond } \\
\text { yields, which would increase borrowing costs for } \\
\text { companies and could stall Japan's efforts to revive its } \\
\text { battered economy. (E\&PN,CENTER); (FS-OTHER, } \\
\text { PERIPHERY) }\end{array}$ \\
\hline 5-Mar-99 & & & & 86 & & & $\begin{array}{l}\text { G7: Labor department eported hourly wages rose } \\
0.1 \text { percent in February, less than the } 0,3 \text { percent } \\
\text { forecasted. Unemployment went up } 0.1 \text { percent point. } \\
\text { (E\&PN, CENTER) }\end{array}$ \\
\hline 16-Apr-99 & & 57 & & & & & $\begin{array}{l}\text { ASIA: Influx of European funds brought up Asian } \\
\text { stocks posting sharp gains throughout the region. } \\
\text { (FS-OTHER, CENTER) }\end{array}$ \\
\hline 19-Apr-99 & & 57 & & & & & $\begin{array}{l}\text { ASIA: Investors fell confident that the global financial } \\
\text { crisis is largely over. (FS-OTHER, PERIPHERY) }\end{array}$ \\
\hline 26-May-99 & & & & & 71 & & $\begin{array}{l}\text { LA: Markets rebound as fears concerning Argentina's } \\
\text { ability to maintain its currency board (as well as fears } \\
\text { about a potential political scandal involving Brazilian } \\
\text { President Cardoso) subside. } \\
\text { PERIPHERY); (E\&PN, PERIPHERY) }\end{array}$ \\
\hline 29-July-99 & & & & 57 & & & $\begin{array}{l}\text { G7: Investors were relieved when Alan Greenspan } \\
\text { offered nothing new to upset global markets in a } \\
\text { testimony to US lawmakers. (MP, CENTER) }\end{array}$ \\
\hline
\end{tabular}

\section{Notes:}

FS: $\quad$ News from the financial Sector. They could either originate in the banking sector (BANKING) or not (OTHER). MP: News about Monetary Policy

E\&PN: News about the economy (excluding the financial sector) and political news.

IA: Refers to international agreements or policy coordination actions

Numbers in cells represent the percentage of countries in their respective region (or world) experiencing turmoil on that day.

The parenthetical statements after each news event explain the region from which news originated and our classification of news. For example, On July 29,1999; 57 percent of the G7 countries were affected by Alan Greenspan's testimony. His testimony was classified as Monetary Policy News originating in the Center (MP, CENTER). 